\title{
Grundtvig på anklagebænken. En redegørelse for hovedlinjer $i$ de sidste ti års danske Grundtvig- reception og deres forhold til centrale motiver $i$ Grundtvigs forfatterskab og dets virkningshistorie.
}

\author{
Af Kim Arne Pedersen
}

\section{Indledning: Grundtvig og den danske identitet ${ }^{l}$.}

Har forskellene Danmark og Sverige imellem forbindelser til Grundtvigs indflydelse på dansk kultur? Spørgsmålet lader sig kun bęsvare, hvis man gør sig klart, hvilke forskelle der er tale om. Sammenligninger mellem Danmark og Sverige er almindelige i begge lande og er vidnesbyrd om, at man begge steder tænker ud fra den grundantagelse, at der består et slægtskab mellem de to lande, der sætter forskellene i relief. Under den seneste tids debat om dansk »fremmedfjendtlighed «, afstedkommet af diskussionen mellem Mona Sahlin og den danske integrationsminister Bertel Haarder blev Grundtvig i et enkelt tilfælde inddraget i debatten om forskellen på dansk og svensk (se hertil nærværende artikel s. 217f.). Selv plejer jeg at sige, at forskellene kommer markant til orde, når man sammenligner strømninger i de respektive lande i de første år efter afslutningen af Anden Verdenskrig. Indtil krigen var både Sverige og Danmark præget af indflydelse fra tysk kultur. I begge lande kom den angelsaksiske, analytiske filosofi til at spille en rolle i efterkrigstiden. I Sverige blev denne retning imidlertid langt stærkere end i Danmark og stod centralt i forbindelse med den meget væsentlige debat om tro och vetande, som filosoffen Ingemar Hedenius (1908-82) afstedkom med sine stærkt religionskritiske og antiteologiske værker (artiklen 'Ingemar Hedenius', Den store danske Encyklopcedi, VIII, s. 319). Jeg plejer i den forbindelse at pege på det påfaldende $\mathrm{i}$, at det danske, intellektuelle kulturmiljø i samme periode prægedes af en åbenhed over for religiøsitet og kristendom, der stod i forbindelse med miljøet omkring det litterære tidsskrift Heretica. Kredsen bag dette tidsskrift var langtfra præget af enighed. Men fælles for de fleste af dens

1. Dette arbejde er blevet til på Grundtvig-Biblioteket Vartov, og dermed $\mathrm{i}$ Grundtvig-Akademiets regi. Jeg takker Kirsten og Hans Grishauge, Henrik Wigh-Poulsen, Liselotte Larsen og Lise Mortensen for hjælp og støtte. 
medlemmer var en optagethed af den store danske religionshistoriker Vilhelm Grønbech (1873-1948), hvis kulturfilosofi spiller en væsentlig rolle i forbindelse med tidsskriftets ånd og grundpræg:

Med titlens betydning af ' $k æ t t e r i e r$ ' vendte man sig mod rationalismen og de herskende ideologier og hævdede i stedet poesien og den kunstneriske erkendelse som vej ud af efterkrigstidens kulturkrise, der blev tilskrevet intellektets herredømme siden renæssancen (Torben Brostrøm, 'Heretica' i Den store danske encyklopaedi, VIII, s. 399)

Dermed er ikke sagt, at Heretica-strømningen i dansk åndsliv udelukkende havde et kristent præg. Men det forhold, at kredsen talte én af Danmarks største forfattere, prosaisten Martin A. Hansen, hvis forfatterskab bæres af en kristen livsanskuelse, er med til at vise, at kirke og kristendom spiller en rolle i efterkrigstidens danske kultur. For Martin A. Hansens vedkommende brydes en stærk indflydelse fra Kierkegaard med en svagere grundtvigsk prægning, og det er betegnende, at Vilhelm Grønbechs berømte essay om Kierkegaard og Grundtvig som eksponenter for europæiske tendensers nedslag i dansk kultur ligger bag Martin A. Hansens overvejelser over Grundtvigs betydning i essaysamlingen Leviathan ${ }^{1}$. Grønbech repræsenterer en tolkning af Grundtvig som livets og livsviljens talsmand, en livsfilosofisk orienteret forståelse af Grundtvig, som fokuserer på Grundtvigs bestræbelser på at bryde med den individualisme og legemsfjendtlighed, der udgør en skæbnesvanger arv i Vesteuropa ${ }^{2}$. Det er karakteristisk, at Grundtvig for Grønbech "varsler fremad mod en ny kultur", »forlanger en menneskehed der vil sætte samfund i steden for isolation «, »livet i steden for beskuelse og nydelse af livet « (Vilhelm Grønbech, 'Kierkegaard og Grundtvig, 1930' i Kampen om Mennesket, 1933, 2. Udg. Kbh 1950, s. 150) ${ }^{3}$. Når Vilhelm Grønbech kan knytte til ved Grundtvig i sine bestræbelser på at bryde med individualismen, som for ham udgør et sygdomstræk i den vesteuropæiske kultur, vidner det om, at Grundtvig fra årene omkring Første Verdenskrig og frem gennem mellemkrigstiden gradvist opnår den status som uløseligt forbundet med dansk, national identitet, som han har besiddet op til det sidste tiår af det 20. århundrede ${ }^{4}$. Dermed være ikke sagt, at dansk identitet alene er bestemt af Grundtvig og den grundtvigske indflydelse. Den danske forfatter Erik Aalbæk Jensen har i en række interviews træffende sagt, at dansk kultur er afhængig af tre 
»vandårer« tre »fælles sammenhænge«, der »bærer« Danmark: den pietistiske, den kulturradikale og den grundtvigske strømning, vandårer, der spejler sig i hinanden, påvirker hinanden og brydes i et stadigt spil, der udgør danskernes "fælles forståelse $\aleph^{5}$. I sin tematisering af den pietistiske strømnings krav til den enkelte om personlig tilegnelse af kristendommen og dermed pietismens appel til personlig selvransagelse og overtagelse i valg, kulturradikalismens videreførelse af oplysningstidens frigørelsestænkning og den grundtvigske retnings bestræbelserpå at skabe en folkelig samfundskultur glemmer Aalbæk Jensen en fjerde, vigtig faktor: den socialistiske arbejderbevcegelse, hvis indflydelse $\mathrm{i}$ Vesteuropa ikke er gået Danmark forbi, og hvis tanker om social lighed i nærværende artikel opfattes som en væsentlig baggrund for nutidens danske selvforståelse. På mange måder har den socialistiske eller socialdemokratiske strømning kunnet spille sammen med dén grundtvigske indflydelse på dansk samfundskultur, som Erik Aalbæk Jensen i de førnævnte interviews havde en mere eller mindre skjult sympati for. Da Erik Aalbæk Jensen fremsatte sine udtalelser lidt før midten af 1990erne, kunne han endnu gøre dette på baggrund af næsten total accept af »det grundtvigske« i dansk kultur som værende i besiddelse af positive konnotationer og som værende udtryk for en progresssiv tendens i nyere dansk historie. Samtidig er Aalbæk Jensens udtalelser et vidnesbyrd om, at debatten om dansk identitet var blevet åbnet $i$ årene efter murens fald i 1989, og at »danskhed« ikke længere var en selvfølgelig størrelse.

Erik Aalbæk Jensen døde umiddelbart efter udgivelsen af den bog, der foranledigede de nævnte udtalelser, og oplevede således ikke, hvorledes debatten om Grundtvig tog en radikalt ny vending i de følgende år med tiden omkring 1992 som en spæd begyndelse og tiden omkring 1998 som en vigtig mellemstation frem til den allernyeste tid. Det er afgørende for forståelsen af hovedstrømninger i nyere dansk historie og samfundskultur, at holdningen i den danske offentlighed til Grundtvig og den grundtvigske arv i de seneste år har været overvejende negativ, båret frem af en polarisering $\mathrm{i}$ dansk debat, der som sidestykker i nyere tid kun har efterkrigstidens debat om holdningerne under den tyske besættelse i årene 1940 til 1945 og om Danmarks tilslutning til det europæiske fællesmarked i årene omkring og efter 1972. At Grundtvig har haft en selvfølgelig status som det måske væsentligste element $i$ dansk kultur indtil nu, er således baggrunden for, at han spiller en hovedrolle i diskussionen om danskhed i disse år. Lad mig stille det lidt firkantet 
op. På den ene side har vi kredse med tilknytning til pastor Søren Krarups højreorienterede teologisk-politiske bevægelse Tidehverv, der igen har tætte forbindelser til Pia Kjærsgaards Dansk Folkeparti, - og, hvis vi bevæger os ud i de meget fanatiske og sekteriske grænseegne, Den Danske Forenings Peter Neerup Buhl. Disse forsøger alle at monopolisere Grundtvig. Enten bruges hans tanker som argument for, at kristendom og danskhed hører sammen - Pia Kjærsgaard har gjort det - eller hos Peter Neerup Buhl som argument for, at der skal skelnes skarpt mellem danskhed og kristendom, sådan at forstå, at kristendommen »viser mennesket tilbage « på dets givne vilkår, på danskheden. Det er imidlertid vigtigt at holde fast $i$, at man kun i visse tilfælde kan placere repræsentanter for de grundtvigske miljøer i Danmark inden for denne gruppe ${ }^{6}$.

På den anden side finder man kredse med en mere eller mindre løs tilknytning til traditionelle kulturradikale miljøer i Danmark. Her bliver Grundtvig skarpt afvist som idémanden bag den første gruppes tale om danskhed. Grundtvig fremstilles her som en nationalist, hvis danskhedsideologi og forplumrede sammenkædning af danskhed og kristendom har gennemsyret dansk kultur og samfundsliv. Nynationalismen er for disse kredse en logisk følge af hele Grundtvigs tænkning. Blandt Grundtvigs kritikere møder vi så forskellige personer som kulturdebattøren Klaus Rothstein og pastor Leif Bork Hansen, der har praktiseret civil ulydighed og har skjult udviste flygtninge. Sidstnævnte bruger Kierkegaards tale om fordringen til at sige, at Kierkegaard er tættere på sand kristendom, end Grundtvig er ${ }^{7}$. Kritikken af Grundtvig er således overvejende foranlediget af debatten om dansk, national identitet, men den rummer også andre temaer, der ind imellem også kædes sammen med spørgsmålet om danskhed. Væsentligt er her en diskussion af Grundtvigs frihedsbegreb, hans prægning af den danske undervisningstradition og hans forhold til de bærende elementer i den danske velfordsstat. De kredse, der afviser Grundtvig, har vind i sejlene. Selv om Danmark har fået en ny regering, er den kulturradikale indflydelse på kultur, undervisning og medier stadigvæk stærk. Grundtvig er, som det fremgår af ovenstående titel, kommet på anklagebænken.

Nærværende arbejde sigter mod at give en belysning af først Grundtvigs receptionshistorie og dernæst de seneste ti års Grundtvig-debat for med sidstnævnte som afsæt at gennemføre en drøftelse af rimeligheden i de anklager, der rettes mod Grundtvig. I det umiddelbart følgende vil jeg som en del af nærværende arbejdes indledningsstof først forsøge at 
tegne et billede af Grundtvigs position i dansk åndsliv og samfundskultur i tiden fra $0.1883 \mathrm{og}$ frem til slutningen af det 20. århundrede. Jeg griber her tilbage til vigtige stationer i den grundtvigske receptionshistorie, idet jeg fokuserer på en række motiver og begreber i Grundtvigs forfatterskab, der har spillet en central rolle i fortolkningen af hans tanker. Det drejer sig her om folkelighedsbegrebet, der står centralt i forfatterskabet, og i tilslutning hertil det grundtvigske frihedsbegreb, dernæst folkelighedens sammenhæng med Grundtvigs tanker om social ligevcegt og samfundets styreform og endelig oplysningsbegrebet og dermed de grundtvigske skoletanker. At Grundtvigs kristendomsopfattelse ikke omtales i forbindelse med de øvrige nævnte sammenhænge, er der en særlig pointe i. Det skulle hen imod artiklens slutning blive klart, at den glemsel, der i et vist omfang omgiver Grundtvigs teologi i den danske offentlighed, er med til at tilføre forståelsen og fortolkningen af hans tanker en skævhed, der har været med til at bestemme den førnævnte negative retning i den nyeste receptionshistorie. Med udgangspunkt i denne skævhed rundes artiklen af med en hurtig skitse til en Grundtvig-tolkning, der ikke blot tilfører det negative billede væsentlige nuancer, men i visse tilfælde bryder med den gældende opfattelse og fremholder en forståelse af Grundtvig, der på den ene side peger på et almenmenneskeligt element i forfatterskabet, som uden videre kan vinde tilslutning også hos moderne mennesker, på den anden side bæres af den grundantagelse, at der her er tale om en kristen humanisme, hvorfor kun et åbent blik for det grundtvigske univers's forankring i kristendommen kan åbne for disse væsentlige indsigter. Skitsen følger her den førnævnte begrebsmæssige sammenhæng med den væsentlige undtagelse, at Grundtvigs kristendomssyn stilles i spidsen og »farver « de øvrige begreber. Som det fremgår af den hurtige oversigt over artiklens indhold, er dens overordnede tilgang til Grundtvig tildels receptionshistorisk. Derved forstås den beskæftigelse med fortolkningshistorien fremfor med teksterne selv, som er blevet til i forlængelse af den tyske filosofiske hermeneutiks fokusering på virkningshistoriens betydning for teksttolkningen. I forbindelse med enkeltanalyserne følges den tyske begrebshistoriske skole, der med Reinhart Koselleck som en fremtrædende repræsentant gennemfører en analyse af begrebers samfundsmæssige gennemslagskraft som udtryk for socialhistorisk betingede forandringer, her i særdeleshed moderniteten, der i århundredet fra 1750 til 1850 som den afgørende »Sattelzeit« i Vesteuropa sætter sig igennem som en følge af bykultur, borgerskab og industrialisering og dermed 
bryder med det gammeleuropæiske, statiske agrarsamfund ${ }^{8}$. I nærværende arbejde fortolkes Grundtvig som et led i den proces, hvorigennem det moderne vinder indpas i en dansk kontekst, og de begreber, som han giver en central placering i dansk samfundskultur, opfattes derfor, når det gælder de profanhistoriske sammenhænge, som moderne begreber, hvis dynamiske tilpasningsevne til successive forandringer og skift i den danske, samfundsmæssige kontekst er en legitim følge af Grundtvigs egen innovative evne til i udformningen af sin begrebsverden kreativt at reagere på sin tid og det samfund, han levede $i^{9}$. Artiklens receptionshistoriske ansats medfører imidlertid det førnævnte forhold, at udgangspunktet er Grundtvigfortolkningen i Danmark, hvis væsentlige epoke fra 0. 1883 til 1972 skildres i glimt, før hovedlinjerne i de sidste 10 års Grundtvig-debat forsøges opridset. Kun når det er strengt nødvendigt, griber artiklen i sine første hovedafsnit til egentlige redegørelser for det indhold, Grundtvig selv lagde i sine begreber. Hovedsigtet er i artiklens hoveddel at tematisere fortolkninghistorien, og først hen imod slutningen bliver der tale om en egentlig Grundtvigtolkning. Alligevel skal der her i tilknytning til ovenstående begreber gives en yderst knap indføring i Grundtvigs forståelse af sine idéer. Denne indføring støtter sig på den beskrivelse af sit virke, som Grundtvig udarbejdede hen imod slutningen af sit liv i forbindelse med sin karakteristik af den nyeste europæiske historie. Tekstsammenhængens opfattelse af kristendommens kulturskabende kraft i den universalhistoriske sammenhæng er typisk for Grundtvig, og han karakteriserer her sin indsats som det at give stemme til »en kiæk og lys Betragtning af Menneskelivet i alle dets baade folkelige, kirkelige og videnskabelige Forhold« (N. F. S. Grundtvig, 'Det nittende Aarhundrede eller Folkeligheden, Grækenland og Høinorden, Haandbog i Verdens-Historien', Udvalgte Skrifter (US) v. H. Begtrup, I-X, 1904-1909, VII, s. 703). Grundtvig indfører dermed sin tredeling af menneskelivet i kirke, folk og skole. I det følgende gør han rede for, hvordan dette lyse menneskesyn har ført til, at man i Danmark er nået til indsigt $i$, at menneskets gudbilledlighed, som er knyttet til taleevnen, ikke gik tabt ved syndefaldet, men at mennesket på grund af denne er i stand til at høre Guds tiltale. Denne tiltale kommer for Grundtvig til udtryk i Jesu mundsord, der som gudstjenestens grund og hjerte står over Bibelens døde skriftord. Af disse mundsord har Den Apostoliske Trosbekendelse for Grundtvig størst tyngde, og den er det da også, som udgør kernen i Guds bestandigt samtalende, »fri Vexelvirkning« (N. F. S. Grundtvig, 'Folkelighed og Christendom', US IX, 
s. 85) med mennesket, den vekselvirkning mellem kristendommen og folkeligheden, der fører til menneskets bestandigt mere uddybede forståelse af sit liv i en universalhistorisk progression, der først slutter med Guds riges komme. I verdenshistoriens sidste epoke spiller de nordiske folkeslag en central rolle, og den danske folkelighed giver det danske folk ekstraordinært gode betingelser for at tage imod evangeliet og lade det virke i menneskeslægtens forskellige, kulturelle sammenhænge, betingelser, som Grundtvig ser udtrykt i den nordiske mytologi (N. F. S. Grundtvig, 'Det nittende Aarhundrede', US VII, s. 703). Folkelighedsbegrebet står centralt i Grundtvigs antropologi, idet menneskeslægtens forskellige nationer for Grundtvig hver virkeliggør et aspekt af gudbilledligheden, $\mathrm{i}$ de senere år med stigende styrke forbundet med personificeringen af de enkelte folkeånder som englemagter, der styrer de enkelte folkeslag, forudsat disse tager imod styrelsen i frihed (ibid., s. 702). Begrebet folkelighed rummer således som grundelement betydningen nationalitet, men det er karakteristisk for Grundtvigs forfatterskab, at han ved at skrive det som Folke-Lighed giver det bibetydningen lighed og således markerer, at samhørigheden i et folk i en vis forstand stiller dets medlemmer lige, idet folkeligheden udgør dér, folkets medlemmer alle har del i på lige vilkår (N. F. S. Grundtvig, 'Tidens Løsen og Nordens Pris', Danskeren 5/9 1848, No. 16, s. 242 f. og N. F. S. Grundtvig, 'Den danske, den tyske og den franske Sag', Tale i Den Slesvigske Hjælpeforening, Danskeren 1848 , s. $213 \mathrm{ff}$.) ${ }^{10}$. Det er nærværende forfatters opfattelse, at det centrale begreb vekselvirkning og dermed forholdet mellem Gud og menneske som et frit forhold udgør kærnen i Grundtvigs frihedsbegreb, ligesom det centrale begreb livsoplysning for Grundtvig udspringer af den stadige dialog mellem Gud og menneske og dybest set sigter mod at lade mennesket opnå indsigt $\mathrm{i}$ sin gudbilledlighed. Livsoplysningen udspringer af folkelivet, men sættes af kristendommen ind i en universalhistorisk ramme. Modernitetens gennembrud kommer til udtryk i Grundtvigs forfatterskab derved, at de nævnte begreber lader sig anvende og forstå i en human kontekst, hvor deres religiøse og kristne betydning fortones. Samtidig er det hovedsigtet at vise, at dette i et udviklingshistorisk perspektiv også medfører en fortegning af begreberne, der dels gør det muligt at udnytte dem i en markant nynationalistisk kontekst, dels blotter dem som angrebsmål for anklager mod Grundtvig for en manglende human indstilling til fænomener i samfundet og kulturen. 
II. Grundtvig som fortolkeren af den danske identitet - Grundtvigreceptionen i perioden 1883-1972.

I indledningen blev der gjort rede for, hvorledes den positive holdning til kirke og kristendom i betydelige kredse $\mathrm{i}$ den danske efterkrigstidskultur rummer tråde til Grundtvigs forfatterskab. Dermed er ikke sagt, at Grundtvig »farver« alt, hvad der i denne tid siges om religiøsitet i almindelighed og kristendom i særdeleshed. Men når kombinationen af religion og kultur forekommer, er der tale om, at der etableres en form for idémæssigt »rum« eller zone, hvor skribenter og tænkere kan føle sig i overensstemmelse med Grundtvig og grundtvigske motiver og da direkte gribe til tolkninger af hans forfatterskab. Sammenhængen giver sig af Grundtvigs egen sammenstilling af religion og nationalt forstået kultur, det begrebspar, han som før nævnt kaldte for »Folkelighed og Christendom «. Imidlertid er det væsentligt for forståelsen af Grundtvigs stilling i årene efter hans død i 1872, at han på det tidspunkt langtfra havde den selvfølgelige status i dansk kultur, som han făr fra $1914 \mathrm{og}$ frem, $o g$ at Edvard Brandes som en fremtrædende repræsentant for det, der her betegnes som den kulturradikale strømning, i sin kritik af Grundtvig netop fæstner sig ved, hvad han opfatter som den manglende indre sammenhæng i Grundtvigs tanker om kristendom og kultur.

En grundigere redegørelse for den grundtvigske "vandåre « i forhold til pietisme, kulturradikalisme og socialisme, end der her kan gives, ville utvivlsomt kunne inddrage de »brudtekster«, hvori man ser pietismen og socialismen afgrænse sig i forhold til den grundtvigske retning. Det er betegnende for forholdet mellem grundtvigianismen og den mest indflydelsesrige pietistiske bevægelse Indre Mission, at dens leder Vilhelm Beck (1829-1901) efter en tid lang at have samarbejdet med grundtvigianerne bryder med disse så tidligt som i 1865 på baggrund af et rent religiøst spørgsmål, spørgsmålet om, hvorvidt der kan gives frelse for uomvendte mennesker efter døden, eller de, som hævdet af pietisterne, går fortabt som en følge af en manglende personlig tilegnelse af Kristus i jordelivet (Vilh. Beck, 'Tør du bede for de døde?', Indre Missions Tidende, 1865, s. 242ff.). En redegørelse for socialismens stillingtagen til Grundtvig kunne gribe fat i stifteren Louis Pios (1841-1894) vurdering af denne i 1872 (Louis Pio, Socialisten, 5/5 1872 ) $^{11}$. Her skal artiklen imidlertid begrænse sig til at konstatere, at avisen Socialdemokraten i forbindelse med fejringen af Grundtvigs 100-års dag i 1883 nøjes med på en af de sidste sider kort at nævne, at »Grundtvigs 100-Aarsdag fejres 
her i Byen af hans Venner fra alle Dele af Landet « (Social-Demokraten, 8/9 1883), idet det således angives, at Grundtvig af socialisterne opfattes som snævert bundet til sine tilhængeres bevægelse, den bevægelse, der netop i 1880-erne truedes af spaltning mellem en højre- og en venstregrundtvigsk retning. Denne spaltning var forbundet med grundtvigianernes politiske stillingtagen samt forskellige holdninger til bibelkritik og moderne litteratur. Venstre- eller »ny «-grundtvigianerne støttede Det forenede Venstre, medens højregrundtvigianerne for en stor dels vedkommende støttede Estrups politik ${ }^{12}$. Den københavnske avis Morgenbladet skulle som venstreavis tilgodese venstregrundtvigianere såvel som de medlemmer af det københavnske borgerskab, der sluttede op om Georg Brandes's kristendomskritiske, kulturradikale emancipationsbevægelse. Avisen bragte først dagen efter Grundtvigs fødselsdag en forbeholden og kølig hyldestartikel, forfattet af førnævntes bror, journalisten, kritikeren og politikeren Edvard Brandes (1847-1931). Artiklen præges af Edv. Brandes's modvillige beundring for Grundtvig, og bæres af nogle iagttagelser, der også i dag har værdi i forbindelse med tolkningen af de grundtvigske idéers gennemslagskraft i det danske folk. Edv. Brandes indleder med at konstatere, at alene Grundtvig blandt det 19. århundredes store danske har formået at samle »en Menighed om sit Navn som en Fane« og at hans væsentlige indsats består deri, samt i det forhold, at han

havde en lysende Frihedstrang, en ubetvingelig og sejersikker Tillid til det frie Ord, som maaske er hans fuldeste Ret til Berømmelse (Edvard Brandes, 'N.F.S. Grundtvig', Morgenbladet 10/8 1883).

Grundtvigs værdi som digter anerkender Edv. Brandes kun modvilligt, nølende og temmelig indirekte, og for ham består de grundtvigske idéers tiltrækningskraft bl.a. deri, at de »besidder en ny Religions Evne til at udstrække sig " (ibid.), dvs. som dynamiske begreber kan tilpasse sig til og indoptage nye fænomener og tankegange al den stund »Læren besidder Udvidelseskraft til at samle forskjelligtænkende Hoveder under samme Ide« (ibid.). Væsentligt i nærværende sammenhæng er, at Edv. Brandes ikke mener, de enkelte elementer i Grundtvigs univers hænger sammen:

Læren er ikke enkelt og den er ikke exakt. Paa det rent religiøse Omraade er den en nem kirkelig Begrændsning, men denne hænger 
ikke organisk, - om end psykologisk - sammen med Grundtvigs Hævdelse af det nordiske og af »Nørreledens « verdenshistoriske Mission. Det praktiske Resultat: Folkehøjskolerne udspringer heller ikke med Nødvendighed af et bestemt Klarsyn paa Almueopdragelsen hos Grundtvig; de blev snarere bagefter indordnede under den hele organisatoriske Bestræbelse. Og endelig det politisk-demokratiske Princip staaer i visse Maader baade fjærnt fra det kirkelige og det nordiske hos Grundtvig. Man kan hævde »den mageløse Opdagelses « Betydning uden at staa fast paa den almindelige Valgrets Grundlov, ja uden at være stoksikker paa, om Mythe og Saga er den bedste aandelige Forberedelse for unge Bønderkarle og Piger « (ibid).

Som det fremgår af citatet, bevæger Edv. Brandes sig i præsentationen af Grundtvigs hovedmotiver mellem Grundtvigs kirkelige virke o $g$ hans kulturelle eller folkelige indsats. De grundidéer, han opregner, følger nærværende artikels systematisering, omend i en anden rækkefølge. Grundtvigs kirkelige hævdelse af den apostoliske trosbekendelse som kirkens mundtligt traderede grund modstilles en række ikke-religiøse motiver, først tanken om de nordiske folkeslags særstilling i verdenshistorien, derefter folkehøjskoleidéen og endelig Grundtvigs politiske tænkning. Intetsteds i teksten optræder det folkelighedsbegreb, der i det 20. århundrede er uløseligt knyttet til Grundtvigs navn, omend det indirekte kommer til udtryk i Edv. Brandes' omtale af "Nørreleden «, idet han her citerer Grundtvigs Haandbog $i$ Verdens-Historien. Væsentligt er, at det for Brandes er afgørende, at de folkelige, dvs. ikkereligiøse motiver ikke står i forbindelse med Grundtvigs kirkelige tænkning i kraft af en indre sammenhæng. Artiklen vakte et vældigt røre og førte til, at Morgenbladet gik ind, hvorefter dagbladet Politiken opstod som organ for Brandes-påvirkede kræfter i dansk politik og kultur. Det er ikke uden betydning, at Danmarks store, kulturradikale avis er blevet til som en følge af Edvard Brandes's kritik af Grundtvig ${ }^{13}$. Teksten har derved status som dén markante brudtekst, hvorved kulturradikalismen skiller sig ud i forhold til den grundtvigske strømning i dansk kultur.

Bevæger man sig 50 år frem i tiden, er billedet et ganske andet. I mellemkrigstiden gennemføres den identifikation af Grundtvig og Danmark, som står som et eksempel på ikke blot Grundtvigs men også grundtvigianismens succes. Hvis der ikke havde været en bevægelse, der skabte miljø og førte Grundtvigs tanker ud i livet, ville der heller ikke være en almen og bred accept af Grundtvig og grundtvigske begre- 
ber. Spændende er, at forbindelsen mellem Grundtvig og ikke-grundtvigske kredse sluttes med den førnævnte nygrundtvigianisme som mellemled, idet denne retnings bestræbelser på at komme århundredskiftets moderne kulturstrømninger og humane fremskridtsbevægelser i møde bygger bro til eksempelvis socialdemokraters knytten til ved Grundtvig og det grundtvigske folkelighedsbegreb. Grundtvig stod centralt i mellemkrigstidens danske politiske og kulturelle debat. Litteraturhistorikeren, professor Vilhelm Andersen fremhævede Grundtvig som »et talende Vidne om Enhedsfølelsen i vort af Partier og Retninger delte Folk« (Jørgen I. Jensen, Den fjerne Kirke. Mellem kultur og religiøsitet, København 1996, s. 402) og skildrede ham i sin litteraturhistorie som »det kraftigste (udtryk) for hans Folks og dets Aands Kamp for at blive sig selv bevidst" (Vilh. Andersen, Illustreret dansk litteraturhistorie, I-IV, III, København 1924, s. 140). Professor P. W. Rubow gennemførte som noget nyt øvelser over Grundtvigs digtning som et led i litteraturstudiet ved Københavns universitet (P.V. Rubow, Smaa kritiske Studier, København. 1935; Gejstlige og verdslige Breve, København 1937; W. Michelsen, Tilblivelsen af Grundtvigs historiesyn, Idehistoriske studier over Grundtvigs verdenskrøniker og deres littercere forudsœtninger, I-II, København 1954, s. 23) ${ }^{14}$. Politikeren og kulturdebattøren Arne Sørensen knyttede til ved Grundtvig i sine bestræbelser på at give stemme til et "tredje Standpunkt" mellem parlamentarisme og diktatur, liberalisme og socialisme (Henrik Lundbak, Staten stork og Folket frit, Dansk Samling mellem fascisme og modstandskamp, København 2001, s. 227ff.), og i en vis modsætning hertil kunne den ovenfor omtalte Vilhelm Grønbech knytte til ved Grundtvig i et forsøg på at forsvare såvel demokrati som humanisme over for de totalitære bevægelsers trussel ${ }^{15}$. Den livsfilosofiske tolkning af Grundtvig som forkynder af liv og livskraft, som nævnes i indledningen, vinder i disse år frem $\mathrm{i}$ en kombination med det billede af Grundtvig som en progressiv fornyer af dansk kultur, som har nygrundtvigianismen som baggrund. I forbindelse med Grundtvigs 150 års fødselsdag fejres han da også i netop de aviser eller deres arvtagere, der i 1883 gav en kølig eller ingen omtale af ham.

Politiken bringer en udførlig omtale af de officielle fester, hvor Grundtvig fejres, og jubilæumskroniken skrives af ingen ringere end højskoleforstander Holger Begtrup fra Frederiksborg Højskole, i samtiden omtalt som »Professor i Grundtvig" (Ole Vind, Harpens Kraft, Frederiksborg Højskole 1995, s. 13ff ). I kronikken betvivler Begtrup 
gyldigheden af den almindelige opfattelse af Grundtvig som historiker og pædagogisk teoribygger i moderne forstand og slår fast, at Grundtvig ikke var nogen af delene, men »En Profet, en Forkynder af Livet, som vi aldrig har haft Mage til i vort Fædreland « (Holger Begtrup, Politiken 8/9 1933).

I Social-Demokraten finder man tilsvarende omhyggelige referater af de nationale sammenkomster, og samtidig finder man elementerne til det, der i disse år kan siges at udgøre en selvstændig, socialdemokratisk Grundtvig-reception. I Arbejdernes Laeseselskab fejres Grundtvig med taler af den københavnske højskoleforstander Johan Borup, en nøgleskikkelse inden for den nygrundtvigske retning og en mangeårig brobygger mellem grundtvigianisme og socialisme, og den socialdemokratiske undervisningsminister og redaktør Frederik Borgbjerg ${ }^{16}$. Borgbjergs Grønbech-inspirerede tale er interessant, fordi den indeholder de elementer, der op til i dag har været bestemmende for billedet af Grundtvigs betydning for dansk kultur ${ }^{17}$. Bag Borgbjergs begejstring for Grundtvigs "ukuelige Livskraft« sporer man Grønbechs tolkning, men det er samtidig karakteristisk, at en egentlig Grundtvig-læsning også danner baggrund, idet Borgbjerg citerer Grundtvigs ovenfor omtalte Tillaeg til Haandbog i Verdens-Historien:

Den Grundtvig, som vi skal fejre i disse Dage, er Aandsfrihedens mægtige Talsmand, Lysséeren og Fremskridtets Ven. Intet Fremskridt bliver til uden et vist Lyssyn. Da Grundtvig var 85 Aar, paa et Tidspunkt, hvor andre forlængst er blevet Jeronimus'er, skrev han, at han vilde forkynde en »lys og kæk Betragtning af Menneskelivet «. Han vilde Frihed for alt, hvad der er af Aand. Han var en ægte Søn af Oplysningens Aarhundrede og »Germanernes Lærling « i langt højere Grad end Karl Gjellerup, men det var ikke Bismarcks og Hitlers Tyskland, han var Tilhænger af (Social-Demokraten, 9/9 1933).

Med indledningen signalerer Borgbjerg, at han vil fremhæve sin fremskridtșoptimistiske og frigørelsesorienterede tolkning i modsætning til tidens andre billeder af Grundtvig. I en receptionshistorisk sammenhæng er det væsentligt, at religionshistorikeren Edv. Lehmanns bog om Grundtvig danner klangbund for Borgbjergs tale, således at forstå, at Lehmanns bestræbelser på at sætte Grundtvig ind i en europæisk oplysnings- og frigørelsestradition følges (Edv. Lehmann, Grundtvig, Køben- 
havn 1929, s. 219ff. $)^{18}$. Samtidig kan Borgbjergs sammenlæsning af Grundtvig og Rousseau muligvis have påvirket Lehmann - ifølge Borgbjergs biograf H. P. Sørensen daterer denne sig tilbage til Borgbjergs ungdom (H. P. Sørensen: F. J. Borgbjerg, København 1943, s. $7 \mathrm{ff})$. Det udhæves med kursiv i avisens referat, hvorledes Grundtvigs tanker ifølge Borgbjerg er uløseligt forbundne med demokrati og frihed:

Naar det danske Folk nu ikke kan smittes af Nazisme og Fascisme, er Aarsagen ikke mindst Grundtvigs mogtige, folkeopdragende Indsats (Ibid.).

Borgbjerg sammenknytter, som det fremgår af et andet referat, Grundtvig med det danske demokrati og understreger, hvorledes Grundtvig »blev en glødende Tilhænger af det frie Folkestyre og den mest udstrakte frie Valgret « (Politiken, 9/9 1933). Heraf fremgår det desuden, at Grundtvig for Borgbjerg har nedlagt sin sociale opfattelse i sin sang om Danmark, almindeligt kendt som Langt højere Bjerge, ordene om at »da har i Rigdom vi drevet det vidt/Naar faa har for meget, og færre for lidt « (N.F.S. Grundtvig, 'Danmarks Trøst', i Poetiske Skrifter, udg. af Svend Grundtvig og Georg Christensen, I-IX, V, s. 64), ved siden af »Frihed for Loke saavel som for Thor" (N.F.S. Grundtvig,, Nordens Mythologi 1832, US V, s. 385) og det nedenfor behandlede »Menneske først « (se s.197 og s. 236) det hypppigst brugte Grundtvig-citat i dansk kultur overhovedet. Borgbjergs tolkning af Grundtvig som bolværket mod de antidemokratiske strømninger korresponderer med filologen, den socialdemokratiske politiker Hartvig Frisch's (1893-1950) udgivelse af bogen Pest over Europa, København 1933, hvori Frisch - med en udtalt vilje til at tænke inden for nationalstatens rammer - i indledningen drager paralleller mellem den grundtvigske bondestands kamp for det parlamentariske demokrati og arbejderbevægelsens nutidige kamp for "det sociale demokrati« (H. Frisch, Pest over Europa, 1933, Ny. udg. 1993, s. 13). ${ }^{19} 11935$ bliver Borgbjerg, - der af sin samtid opfattedes som en stor taler (H.P. Sørensen, Frederik Borgbjerg, København 1943, s.152) - af Gyldendal bedt om at tale om nutiden set med en historisk persons øjne og vælger da, delvis på eget initiativ og delvis under inspiration fra Edv. Lehmann, at lægge stemme til Rousseau (Edv. Lehmann, Grundtvig, København 1929, s. 220ff.). Talen er et godt eksempel på Borgbjergs udgangspunkt i århundredskiftets optimistiske tro på den menneskelige frigørelses og naturvidenskabernes fremskridt - 
Borgbjerg fremhæver »Humanismens Idéer « og taler med begejstring om »Udviklingen «, et begreb, hvis betydningsindhold giver sig af fraværet af klassiske marxistiske begreber som »klassekamp« og »dialektisk materialisme«. Og samtidig er talen et markant led i folkelighedsbegrebets historie i Danmark, al den stund den »folkelige Betydning " (SocialDemokraten 9/9 1933), som Borgbjerg i sin jubilæumstale peger på, her direkte făr udtryk i en forening af nøgleord fra henholdsvis det grundtvigske og det socialdemokratiske univers. Borgbjerg lader i sin tale Rousseau sige, at hvor det 19. århundrede prægedes af Voltaires »Liberalisme og Aandsaristokrati«, vil det 20. blive præget af hans »Folkelighed og Socialisme«. Folkelighedsbegrebet fører Borgbjerg frem til at karakterisere de nordiske lande som »modeller« for udviklingen mod socialt og demokratisk fremskridt:

Folkeoplysning, Folkestyre, Stræben efter social Retfærdighed og dermed efter et crligt Folkefællesskab og sand Kristelighed har trods tidvist og stedvist Tilbageslag vundet en Udbredelse og Indflydelse som aldrig før. Jeg, Borgeren fra Genève, de antike Republikers Beundrer, var vel begrænset i min Statsopfattelse, men mon alligevel ikke de smaa Stater har visse Betingelser forud for de store paa disse Omraader? Jeg retter forhaabningsfuldt mit Blik mod Nordstjernens Lande og Folk« (H.P. Sørensen, F. J. Borgbjerg, København 1943, s. 157-159).

Borgbjergs begejstring ikke blot for Danmark, men, - helt i Grundtvigs ånd - for Norden og de nordiske lande korresponderer med samvirket mellem de nordiske socialdemokratier i disse år ${ }^{20}$. Væsentligt i nærværende sammenhæng er det forhold, at Borgbjerg i den førnævnte jubilæumstale såvel som $i$ talen, hvor Rousseau ser sine tanker realiseret i en dansk og nordisk sammenhæng, tildels lader Grundtvigs kirkelige grundtanker fremtræde adskilt fra hans folkelige indsats, idet de kun forbindes med Grundtvigs frihedssyn og samtidig giver Borgbjerg anledning til en polemik mod både folkekirke og kirkelig grundtvigianisme. Grundtvigianerne har ikke formået at følge den Grundtvig, hvis tanker om kirkelig frihed for Borgbjerg med nødvendighed må føre til adskillelse af stat og kirke, og som det fremgår af ovenstående citat fra 1935 er kernen i kristendommen for Borgbjerg lig den menneskelige frigørelse i social henseende, hvis begyndende realisering i de nordiske lande han mener at opleve. Borgbjergs tale er et fremtrædende eksempel på, at den 
åbning over for det moderne gennembrud i litteratur og samfundstænkning, som nygrundtvigianismen har medført, i forbindelse med Grundtvig-receptionen i ikke-grundtvigske miljøer får den konsekvens, at Grundtvigs kirkelige indsats rangeres ud på et sidespor. Dén Grundtvig, som kan bruges i Socialdemokratiets nationbuilding, er ikke teologen Grundtvig, og Borgbjerg er i sin tænkning grundlæggende bestemt af det danske Socialdemokratis massive antikirkelige polemik fra grundlæggelsen i $1872 \mathrm{og}$ hen over århundredskiftet. Imidlertid medfører udviklingen i dansk kirke- og kulturliv op til, under og efter den tyske besættelse, at det grundtvigske forfatterskabs teologiske nerve fremfor at underkastes glemsel bliver udgangspunktet for nye fortolkninger, der $\mathrm{g} ø \mathrm{r}$ det muligt for efterkrigstidens mennesker at bevæge sig mellem socialdemokratiske, intellektuelt-kunstneriske og kirkelige miljøer, uden at disse opleves som radikalt fremmede for hinanden.

I Danmark er det almindeligt at føre Grundtvigs position i nyere dansk historie tilbage til den »Grundtvig-renæssance«, som i årene under den tyske besættelse 1940 til 1945 indgår i det danske samfunds bestræbelser på at finde ind til nationale værdier i en krisetid. Litteraturhistorikeren Helge Toldbergs iagttagelse, at »flertallet af Grundtvig-forskerne var i gang med Grundtvig inden besættelsen " (Helge Toldberg, 'Moderne Grundtvig-litteratur', Dansk Teologisk Tidsskrift 1946, s. 43), kan imidlertid som før nævnt udstrækkes til at gælde interessen for Grundtvig i den brede, danske offentlighed i mellemkrigstiden. Der er dog ingen tvivl om, at besættelsen er med til at skabe grobund for beskæftigelsen med Grundtvig i efterkrigsårene. Under besættelsen kunne Grundtvig danne udgangspunkt både for digterpræsten Kaj Munks opfordring til væbnet modstand mod den tyske besættelsesmagt (Kaj Munk, Egelykke, Skuespil, København 1940) og for Hal Kochs opfordring til modstand $\mathrm{i}$ form af besindelse på kristne, nationale og demokratiske værdier (Hal Koch, Grundtvig, København 1943). Uden at være partimedlem betragtede Hal Koch sig selv som en venstreorienteret socialdemokrat (P.G. Lindhardt, 'Hal Koch', Dansk Biografisk Leksikon, I-XVI, København 1981, VIII, s. 116), men samtidig med, at han således forholder sig til den endnu i 1930'erne stærkt kirkekritiske bevægelse, bliver det grundtvigske folkelighedsbegreb med ham så at sige »ført tilbage« til den forankring i et kristent univers, som Grundtvig gav det. Hal Koch trækker i sin Grundtvigtolkning på inspirationer fra flere sammenhænge. I Kochs bog om Grundtvig, oprindelig holdt som forelæsninger på Københavns Uni- 
versitet, sporer man elementer af barthiansk åbenbaringsteologi, eksistensfilosofi og Vilhelm Grønbechs livsfilosofi. Grundtvigs livtag med »eksistensproblemet «(K.E. Bugge, Skolen for livet. Studier over N. F. S. Grundtvigs paedagogiske tanker, København 1966, s.162-163) i tekstfragmenterne Om Menneskets Vilkaar tolkes af Koch sammen med den inspiration fra Grønbech, som bliver tydelig, når man læser hans beskrivelse af, hvorledes dunkelheden hos Grundtvig står i forbindelse med »Livets egen Hemmelighedsfuldhed « (H. Koch, Grundtvig, København 1943, s. 19), men samtidig knytter Koch dette sammen med et nationalt anliggende og taler om kravet til ungdommen om en - ikkevæbnet - »Kamp for dansk Aand og Tunge« (ibid. s.13). Inden for de senere år har man diskuteret, hvad der er kernen i Hal Kochs tale om folkelighed. Oplysningshistorikeren Ove Korsgaard har argumenteret for, at det er Hal Kochs sigte at skille politik og kultur og derved bringe folkelighedsbegrebet på afstand af dets nationale grundbetydning ${ }^{21}$. Andre - eksempelvis Leif Bork Hansen i det note 7 nævnte mundtlige indlæg - har peget på Hal Kochs skarpe afvisning af enhver form for international kosmopolitisme, der for den såvel grønbechsk som barthiansk og eksistensteologisk påvirkede Hal Koch er lig med »Værdier « og dermed noget mennesket selv »skaber" (Hal Koch, 'Virkelighed' i Lidt af hvert, København 1940, s. 13), frem for at få det givet af Gud. I den sammenhæng har de talt for en national fortolkning af Kochs folkelighedsbegreb. I en af sine absolut sidste tekster, forfattet som redegørelse for sin positive holdning til Danmarks indtræden i det europæiske fællesmarked, giver Hal Koch imidlertid en markant tolkning af folkelighedsbegrebet, der viser, at han forbinder det med kultur, men netop ikke med den fælleseuropæiske finkultur. På dansk kan folkelighed både betyde plat lavkultur og grundtvigsk farvet, national samhørighed. For Hal Koch svinger folkelighedsbegrebet mellem den nationale samhørighed og den universelle kerne, som alt menneskeligt samliv rummer ${ }^{22}$. Han kan således »oversætte" begrebet med ordene »menneskelighed eller fællesskab « (Hal Koch, 'En livsform skal stå sin prøve', i Meninger om foellesmarkedet, red. J. Stubkjær, København 1963, s. 87) og gøre det klart, at ordet og dets indhold har med »kultur« (ibid., s. 89) at gøre:

Bag det ligger en livsholdning, en livsform - den paideia, som i grunden var kernen i selve den græske kultur. Kultur er ikke et spørgsmål om videnskab og teknik, om kunst og litteratur - men om at være menneske. Menneske er ikke noget, man uden videre er - 
hvorefter det gælder at blive geni eller nobelpristager - men det at være menneske er en opgave, der daglig stiller sig for os alle og væsentlig ens, hvad enten vi får nobelpris og bliver konferensråd, eller vi ikke gør det. Det er ikke tilfældigt, at dansk folkehøjskole bevidst - ikke altid med stort held - det skal siges - har stræbt efter at være en sokratisk skole, en skole til at forstå menneskelivet og dets kår. $\mathrm{Og}$ det er til syvende og sidst denne paideia, der ligger bag vore nordeuropæiske samfund og livsformer. Det meste er temmelig uhåndgribeligt - men derfor ikke uvirkeligt! Det hænger sammen med frihed og menneskelighed - en fornemmelse af at ethvert menneske forholder sig umiddelbart til Vorherre, ikke er og ikke må underordnes andre. Den fattige er ikke under den rige, den enfoldige ikke under den intellektuelle, kvinden ikke under manden ... lægmanden ikke under præsten, borgeren ikke under embedsmanden" (ibid., s. 90).

Det græske ord paideia betyder opdragelse eller dannelse, - og Hal Koch knytter positivt til ved den græske dannelse som ledet af billedet af eller idealet om, hvorledes mennesket burde være, og dermed til den græske dannelses sigte mod »det politiske menneske» (Hal Koch, 'Werner Jaeger, Paideia. Die Formung des griechischen Menschen, Berlin 1934' i Teologisk Tidsskrift, 5. Rk. Bd 5, 1934, s. 309ff). For Hal Koch rummer folkeligheden tydeligvis komponenten lighed som noget væsentligt, og han gør det i artiklen klart, at denne lighed også indbefatter en social lighed. Citatet vidner om spændingsforholdet mellem kristendom og humanisme i Hal Kochs forfatterskab, og det afdækker, hvorledes folkelighedsbegrebets inderste kerne for Koch udgøres af en kristen universalisme. Samspillet mellem partikulært og universelt, folkelighed og kristendom, har Koch fælles med en anden af tidens store Grundtvigtolkere, forfatteren Jørgen Bukdahl, hvis berømte beskrivelse af de nordiske samfundskulturers udvikling fra almue til folk og dermed også "fra Almuekultur til Folkekultur« (J. Bukdahl, Norden og Europa, København 1947, s. 13) han citerer i teksten. Imidlertid blev det hverken Hal Kochs eller Jørgen Bukdahls Grundtvig, der påkaldte sig størst interesse i 1960ernes danske velfærdssamfund ${ }^{23}$. Den danske teolog og præst Kaj Thaning udsendte i 1963 sin monumentale doktorafhandling i tre bind, omhandlende, hvad han opfattede som Grundtvigs »omvendelse til livet« i 1832. Thaning er i sit teologiske udgangspunkt bestemt af dén særlige variant af Karl Barths dialektisk-teologiske åbenbarings- 
teologi og Rudolf Bultmanns eksistensteologi, som i Danmark er knyttet til bevægelsen Tidehverv. Hvor denne retning som nævnt i indledningen i dag har taget en markant drejning mod en højreorienteret linje, hvor indvandringen og det danske EU-medlemskab bekæmpes, var den i sit udgangspunkt båret af unge danske teologers interesse for samtidens strømninger i politik og kultur. Den afgørende påvirkning har Kaj Thaning således modtaget fra Vilhelm Grønbech, hvis livsfilosofi ligger bag hans bestræbelser på at vise, at Grundtvig i 1832 bryder med en luthersk ortodoks, pietistisk farvet bods-og pilgrimsteologi, hvor jordelivet opfattes enten som en mørkt tegnet forberedelse til det hinsidige eller - ifølge Thaning - højst som værdifuldt i kraft af dets indgåen i en kristen kultursyntese (Mikkel Crone Nielsen, »At tale med de døde" - 'Om sækularisering og hermeneutik i Kaj Thanings forfatterskab', i Grundtvig Studier 2002, s. 142ff.). I 1832 făr Grundtvig øjnene op for jordelivets betydning, og det forhold, at det evige, kristendommen, nu er til for menneskelivets skyld, står for Thaning også i forbindelse med, hvad han opfatter som Grundtvigs sekulariseringsteologisk begrundede adskillelse af kristendom og menneskeliv. Thaning fastholder den almindelige grundtvigske erkendelse, at »mennesket ... må ...være sig selv bevidst « (K. Thaning, Menneske først-Grundtvigs opgør med sig selv, I-III, København 1963, III, s. 621) for at kunne tage imod kristendommen, men hævder, at kristendommen da netop ikke omformer menneskelivet, men befrier det til at være sig selv.

Kristendommen er til for menneskelivets skyld, ikke omvendt, og den konkrete følge heraf er, at eksempelvis den danske folkehøjskole skal virke uafhængigt af kirkelivet. Som det fremgår af det korte referat af Thanings tolkning, er denne teologisk motiveret. Imidlertid er det vigtigt at gøre sig klart, at Thanings teologiske nerve, det forhold, at han netop ønskede, at kristendommen med sin »frisættelse « af menneskelivet skulle være åben over for kulturen, inden for den grundtvigske folkehøjskole førte til, at man i vidt omfang løsnede de traditionelle forbindelser til kirken ${ }^{24}$. Thanings Grundtvig kom et behov i tiden i møde, Danmark udviklede sig i disse år væk fra den traditionelle landbokultur, og $\mathrm{i}$ et samfund, hvor sekulariseringen greb om sig, kunne Thanings tanker let vinde indpas. Hertil kom, at de bånd mellem Heretica-miljøet og især Askov Folkehøjskole, som etableredes op gennem 1950'erne og bestod ind i 1960erne, hvor Heretica-generationens dominans afløstes af en fornyet interesse for den kulturradikale strømning, gav Thaning en position, hvor man lyttede til ham i danske, intellektuelle miljøer ${ }^{25}$. 
Og da den kulturradikale strømning udviklede sig i venstreorienteret retning i kraft af ungdomsoprør og politisk vækkelse, kunne Thanings fremhævelse af Grundtvigs omvendelse til livet - i temmelig stærk modsætning til Thanings egne intentioner - danne afsæt for en Grundtvig-tolkning, hvor Grundtvig oplevedes som værende i overensstemmelse med tidens ønsker om radikale forandringer i samfund og kultur. Det grundtvigske folkelighedsbegreb kunne bruges af tidens politisk bevidste ungdom, og det er væsentligt, at begrebet oplevede en højkonjunktur op gennem 1970'erne ${ }^{26}$. Ind i denne sammenhæng føjede sig nu yderligere den måde at behandle forholdet mellem Grundtvig og hans virkningshistorie, som artiklen strejfede $\mathrm{i}$ forbindelse med Frederik Borgbjergs Grundtvig-reception. På samme måde, som Borgbjerg effektfuldt kontrasterer »den virkelige Grundtvig« og hans knap så radikale disciple, var det også både Hal Ḳochs og Kaj Thanings ønske at nå ind til Grundtvigs intention bagom de fejludviklinger, som den kirkeligtfolkelige grundtvigianisme havde medført. Denne tankefigur har op til i dag vist sig særdeles levedygtig og spiller også ind i forbindelse med den lancering af Grundtvigs kosmologi og filosofi, som kredsen omkring oplysningsforskeren Ove Korsgaard har gennemført (En orm - en Gud. Om mennesket $i$ Verden. (red. Ove Korsgaard, Odense 1997). Det er i denne sammenhæng ikke uvæsentligt at pege på det indlysende forhold, at fortolkerne i den lange, virkningshistoriske sammenhæng fremdrager elementer af Grundtvig, som kommer tiden i møde, og at de deri er negativt afhængige af deres forgængere. Den »rene« Grundtvig findes ikke. Imidlertid fik både Thanings og den venstreorienterede Grundtvigreceptions ønske om at finde bagom grundtvigianismen ind til »Grundtvig selv« følger helt ind i den grundtvigske bevægelse. Ingen har skildret dette bedre end Arne Ørtved, i 1970'erne Danmarks yngste højskoleforstander:

Nu skulle det hele skydes i sænk; men ammunitionen blev hentet hos Grundvig selv. En helt ny Grundtvig blev hentet frem fra de støvede gemmer, og det blev faktisk ret inspirerende. Jeg har allerede næunt Ejvind Larsens lille skrift om Grundtvig og Marx. Nok så inspirerende blev Ebbe Kløvedal Reichs fortælling om Grundtvig: Frederik! Og endnu mere de to herrers teaterstykke: Til kamp mod dødbideriet

Det gjaldt kampen mod stivnede strukturer, mod den intellektuelle og økonomiske elite, mod det stigende bureaukrati, personificeret i 
EF, mod rovdrift på ressourcer og miljøsvineri: Tag det sorte kors fra graven!!!..." (Arne Ørtved, '35 år med det grundtvigske kontinuitet og brydninger’, i Højskolebladet 124. Årg. 9, 1999, s. 9).

Arne Ørtved refererer i citatet til de to kulturpersonligheder, der »tegnede « Grundtvig-interessen i årene omkring 1972, den skønlitterære forfatter Ebbe Kløvedal Reich, hvis Frederik. En folkebog om N. F. S. Grundtvigs tid og liv, København 1972, om Grundtvigs udvikling som præget af erotisk og politisk frigørelse i årene efter 1832 blev læst af store dele af den danske befolkning og stadig oplever nye udgaver, og journalisten Ejvind Larsen, der siden halvfjerdserne har markeret sig med nylæsninger af Grundtvigs forfatterskab, først med udgangspunkt i marxistisk teori (E. Larsen, 'Grundtvig - og noget om Marx', Studenterkredsen, Århus 1974, siden med bogen Det levende ord, København 1983, fra jubilæumsåret $\mathrm{i}$ forbindelse med Grundtvigs 200 års fødselsdag. I sidstnævnte værk analyserer Ejvind Larsen Grundtvig på baggrund af psykoanalysens narcissismebegreb og viderefører således sin aktualisering af Grundtvig ved at følge 1980ernes vending mod menneskets indre og de terapeutiske tiltag, som mennesker i disse år oplevede som nødvendige for personlighedsudviklingen. Med denne udgivelse har nærværende artikel imidlertid bevæget sig ud af den epoke, der omfattede den sidste, store "Grundtvig-renæssance« i dansk kultur og samfundsliv og ind i de år, hvor Grundtvigs status i dansk selvforståelse giver anledning til voldsomme debatter.

III Arene efter 1983 - Grundtvig mellem begyndende højreorienteret hyldest og kulturradikal kritik.

I 1983 fejredes Grundtvigs 200 års fødselsdag i Danmark såvel som i udlandet. I så forskellige samfund som Indien og Canada blev Grundtvig hyldet som grundlægger af højskolebevægelsen og den danske oplysningstradition (K. E. Bugge, Grundtvig og Canada, København 1997, 120). Education for Life, 1983, International Conference on the Occasion of the Bicentenary of N.F.S. Grundtvig, Det Danske Selskab, København 1983, dét, der endnu i 2001 af Højskoleforstander Jørgen Carlsen fra Testrup karakteriseres som »et af vore væsentligste bidrag til verdenskulturen « (J. Carlsen, 'Den mageløse Grundtvig', i Grundtvig Studier 2001, s. 280). I Danmark blev han hyldet af - næsten - alle 
kredse i samfundet, fra det oprindelig indremissionsk funderede Haslev Seminarium over de grundtvigske højskoler til Københavns universitet, hvor et internationalt seminar havde deltagelse af så betydningsfulde navne som Hans-Georg Gadamer og Paul Ricoeur (Sprog, tale og skrift. Indlæg fra Fil. Grundtv.-Kongres, red. P. Kemp, Århus 1984, Haslev Seminariums Elevforenings Arsskrift 1983, Haslev). Få år senere møder vi imidlertid den første kritiske røst, der vover at træde op imod den grundtvigske tradition. Henning Fonsmark, litteraturhistoriker af uddannelse og redaktør af dagbladet Børsen, greb fat i rødderne til dén uhæmmede vækst i det danske offentlige system, som ifølge ham præger den danske efterkrigstid. I Fonsmarks analyser spiller Grundtvigreceptionen en langt større rolle end selve Grundtvigs eget forfatterskab, idet det danske samfunds sammenfatning af »såvel socialistiske som "grundtvigske» træk" (H. Fonsmark, Historien om den danske utopi, København 1990, s. 93), som for Fonsmark udgør den danske velfærdsstats ideologiske rodnet, af ham føres tilbage til først og fremmest Hal Kochs tænkning og virke i årene efter 1945. Det er ikke Fonsmarks primære anliggende at skrive idé- eller begrebshistorie, men snarere at kritisere nutidige tilstande ved at grave sig tilbage til de fejltagelser, der har baggrund i ideologi snarere end realpolitik, dvs. den tænkning, der har afstedkommet Danmarks udvikling til et formyndersamfund, der har lammet den enkeltes muligheder for både at tage ansvar for sit eget liv og gennem en arbejdsmæssig indsats bidrage til en sund samfunds$ø$ konomi. At Fonsmark her som den første griber fat i, hvad Ove Korsgaard i tilslutning til hans analyser har kaldt for »den socialgrundtvigske linje« i nyere dansk politik, er betydningsfuldt (Ove Korsgaard, Kampen om Lyset, København 1997, s. 387). Mindst lige så væsentlig er Fonsmarks efterfølgende opgør med den grundtvigske, pædagogiske tradition, som han opfatter som lammende i forhold til danske skoleelevers dygtiggørelse og videnstilegnelse (H. Fonsmark, Kampen mod kundskaber. Et kritisk essay om en hovedstrømning i danskskolepolitik, København 1996, s. 32), omend denne bog langtfra har spillet den samme rolle som den første studie i velfærdsstatens vækst og dens baggrund. Derimod har Fonsmarks tese om de grundtvigske ideers dominans i dansk kultur og samfundsliv formodentlig påvirket de senere års debat, omend den igen kan være blevet til under inspiration fra Uffe Østergårds mentalitetshistoriske analyse fra 1984, omtalt i nærværende arbejde s. 208f. Fonsmark skildrer, hvorledes »højskoledemokraterne(s)« oprinde- 
lige mistillid til »staten som magtbegreb« afløstes af en socialdemokratisk begejstring for det offenlige og skriver:

Men af denne proces - dette tilsyneladende nederlag - kan der også aflæses noget helt andet: På fundamentale, »folkelige « områder viste det sig i hele perioden, at de "grundtvigske « anskuelser aldeles ikke var blevet isoleret $i$ et enkelt parti og aldeles ikke forblev $i$ det oprindelige gårdmandsmilieu, hvor de havde fået vind i sejlene. Tværtimod viste sig meget af det at blive stående med en sjælden grad af, mere eller mindre synlig, slagkraft inden for alle vælgergrupper og inden for de fleste partier - med kommunisterne (men ikke SF) som eneste undtagelse. De kom inden for Socialdemokratiet til at fungere som en løbende korrektion til den socialistiske idéverden, der var partiets eget udgangspunkt. $O g$ denne inspiration fra et rent nationalt idésæt kom i høj grad til at virke også den anden vej, efterhånden som velfærdsdemokratiet blev bygget op, så de tilbageværende, renlivede højskoledemokrater fik lettere ved at acceptere og identificere sig med den statsmagt, der var under dannelse (Fonsmark, Historien om den danske utopi, s. 92f.).

Det er i forhold til Fonsmarks horisont andre fænomener end den offentlige sektors vækst, der siden 1992 har udgjort baggrunden for den tiltagende Grundtvigkritik i den danske, offentlige debat, - en kritik, der mod slutningen af 1990-erne også forekommer inden for sammenhænge med et grundtvigsk udgangspunkt. Grundlaget er her ikke velfærdsstaten, men den ændrede storpolitiske situation i Europa efter murens fald, globaliseringen og indvandringen i det danske samfund - forhold, der hos den danske intellektuelle elite førte til den begejstring for det europæiske samarbejde, der brød med årtiers EF-modstand blandt ledende venstre-intellektuelle ${ }^{27}$. Litteraturkritikeren og samfundsdebattøren Hans Hauge har - drillende, fordi hans ærinde er at trække tæppet væk under billedet af de seneste års udvikling som en udvikling fra "Enshed til mangfoldighed" - sammenfattet den almindelige opfattelse af indvandringens betydning for udviklingen således:

Danmark er på vej til at blive flerkulturelt og multietnisk. Vi lever nu i et flerreligiøst samfund. Engang havde vi en kultur. Vi tilhørte alle det samme folk. Og vi var stort set alle med i samme kirke (Hans 
Hauge, 'Fra Enshed til mangfoldighed', Kristeligt Dagblad 19/11, s. 99).

Hans Hauge identificerer kort efter to grupper inden for den danske debat om »de fremmede « - wintegrationalisterne, der ser problem og løsning $\mathrm{i}$ begrebet arbejde, og assimilationisterne, der hævder, at de konflikter, der findes, alle er kulturelle« (Hans Hauge, 'Integration ...' Kristeligt Dagblad 15/1 2000). Hauge gør i den sammenhæng opmærksom på, at der er stor spændvidde blandt integrationstilhængerne, svarende til de fremmedfjendtlige og de fremmedvenlige i dansk politik. Skarpere og med direkte henblik på den beslægtede problemstilling national identitet har etnologen Tine Damsholt sammenfattet den nutidige situation i en forenklet, men alligevel træffende beskrivelse:

Det nationale er ... forfærdeligt aktuelt, men også anledning til meget forskellige synspunkter. Både den videnskabelige og den politiske debat kan groft opdeles i to hovedkategorier: en fløj, der ofte kaldes konstruktivister, hævder, at nationerne er vilkårlige størrelser opfundet af de nationalistiske bevægelser for at legitimere krav om selvstyre og politisk indflydelse. Heroverfor hævder såkaldte essentialister, at nationer (eller i det mindste idéen om nationer og folk) har ældgamle rødder og kan følges tilbage til historiens start. De to fløje bruger megen tid på at bekrige hinanden, hvilket formodentlig hænger sammen med, at de, der hævder, at nationer er nye opfindelser, ofte er identiske med dem, der er kritiske over for nationalisme og positive over for EU og/eller det multietniske samfund, mens de, der henviser til nationernes naturlighed og oprindelighed, ofte er tilsvarende skeptiske over for nationalstaternes opløsning, globaliseringen og det multikulturelle« (Tine Damsholt, Kristeligt Dagblad 19/5 2001).

I denne debat er Grundtvig i de seneste år blevet benyttet som ammunition såvel som skydeskive. De fremmedfjendtlige, eller, om man vil, indvandringskritiske grupper, der i den teologisk-kirkelige Tidehvervsbevagelse har deres intellektuelle, og i virkeligheden temmelig elitære spydspids, har som nævnt $\mathrm{i}$ indledningen taget ham til hjerte, hvorimod den anden fløj, i vidt omfang identisk med en mere eller mindre kulturradikalt præget intellektuel elite, har afvist ham som et fuldgyldigt udtryk for en zenofobisk tradition i dansk kultur. Hvorfra 
stammer dette billede - er det en frugt af Tidehvervs, Den Danske Forenings og Dansk Folkepartis brug af Grundtvig, - eller er billedet et korrekt aftryk af Grundtvigs og den grundtvigske traditions inderste kerne, fremanalyseret i skriftlige sammenhænge og i debatten inden de nævnte højrebevægelsers "grundtvigske « kampagne tog fart, eventuelt i en sammenhæng, der trækker på andre indsigter end døgnets debatter? Her må man gøre sig klart, at der i en dansk sammenhæng er tale om en vekselvirkning mellem den offentlige debat om Grundtvig og selve den egentlige forskning, en vekselvirkning, der gør det uhyre vanskeligt at sige, hvad der er årsag og virkning.

Det billede af Grundtvig som en nationalistisk fremmedhader, der toner frem af den offentlige debat i Danmark, står i forbindelse med det forhold, at Grundtvig indgår i den aktuelle debat om national identitet, men det har utvivlsomt også rødder i Århus-historikeren, professor Uffe Østergårds arbejde med at påvise, at folkelighedsbegrebet som al anden national identitet er en »opfindelse « snarere end en opdagelse, blevet til i forbindelse med industrialisering og modernisering af de gamle, statiske agrare samfund i Europa. Udviklingen kan, hvis man vover at give en fremstilling af et endnu ikke helt overskueligt billede, opfattes som havende sit udgangspunkt i Uffe Østergårds forskning, først Europas ansigter, København 1992, derefter Europa, Identitet og identitetspolitik, København 1998. Uffe Østergårds forskning har derudover udmøntet sig i en række »nationstatnumre« (Niels Finn Christiansen, 'Forskellenes Europa. Mangfoldighedens Pris - dansk faghistorie - en status' i tidsskriftet Den jyske Historiker, Århus 1997, s. 164ff). Uffe Østergård har som nævnt ovenfor siden 1980erne med stigende skarphed taget den grundtvigske prægning af det danske samfund under behandling, al den stund han, - efter nærværende forfatters mening ganske præcist, - opfatter den grundtvigske strømning som den væsentligste i den danske identitetsdannelse. Uffe Østergård begrunder dette med, at den grundtvigske tradition også har været bestemmende for bevægelser med et andet ideologisk udspring, først og fremmest det danske Socialdemokrati, i og med at den »har præget deres modstandere bag om ryggen på disses egen selvforståelse (Uffe Østergård, Europas Ansigter, København 1992, s. 78). Uffe Østergårds arbejde med at definere dansk identitet bæres som før nævnt af hans socialkonstruktivistiske bestræbelser på at vise, at »det danske folkelighedsbegreb altid har været en konstruktion« (Niels Henrik Gregersen, 'Den generøse ortodoksi', i Folkelighed år 2000, Vartovs konferenceserie nr. 1, s. 25) og indledes 
med den store fremstilling i Kultur, mentalitet, ideologi, red. O. Bøttzauw et. al., Den jyske Historiker nr. 29-20, Århus 1984, Hvad er det "danske" ved Danmark?, af ham selv præsenteret som en mentalitetshistorisk karakteristik af samspillet mellem de grundtvigske tanker og det danske landbrugssamfund, et samspil, der for Uffe Østergård fører til landbobefolkningens og den grundtvigske traditions »Hegemoni over bybefolkningen« (Uffe Østergård, 'Hvad er det »danske« ved Danmark? Tanker om den »danske vej« til kapitalismen, grundtvigianismen og »dansk" mentalitet' i Den jyske Historiker, Århus 1984). Det er imidlertid karakteristisk for hans udvikling, at positionen fra 1984, året efter Grundtvig-jubilæet, brydes op hen imod 1992, i og med, at han benytter de samme iagttagelser som tidligere $\mathrm{i}$ en ny kombination og med en tysk udgivelse fra et i 1991 afholdt seminar som mellemstation på vej hen imod den første, store udgivelse (U. Østergård, 'Grundtvig, grundtvigianismen og dansk national identitet - metodiske problemer i studiet af Grundtvigs digtning' i Arbeiten zur Skandinavistik, 10. Arbeitstagung für deutschsprachigen Skandinavistik. B. Glienke, u. E. Marold (Hg.) Frankfurt a. M. 1993, s. $387 f f$.). Uffe Østergårds forskning bæres af et stærkt engagement i politik og samfundskultur, en bestræbelse på at gøre op med den danske skepsis over for den europæiske union. I bogen Europa. Identitet og Identitetspolitik griber han fat i det nordiske fællespræg, der giver sig af giver sig af den lutherske kristendomsforms dominans i århundrederne efter 1700-tallets statspietisme, altså i perioden efter modernitetens fremkomst:

Set i det lange historiske perspektiv er de nordiske lande ikke nær så forskellige fra de andre europæiske lande, som den nordistiske ideologi og talen om den skandinaviske model gerne ville have os til at tro. Men de er lutheranske. Næppe fra reformationen i 1536, men fra et tidspunkt i 1700-tallet, hvor de pietistiske vækkelsesbevægelser, som siden blev til de politiske, sociale og økonomiske folkelige bevægelser, slog bredt igennem. Her finder vi muligvis baggrunden for den nordiske velfærdsstat, der i mindre grad skyldes en særlig nordisk samfundsstruktur end det forhold at staterne er homogent lutheranske« (Uffe Østergård, Europa, identitet og identitetspolitik, København 1998, s. 336).

Med dette som udgangspunkt beskriver Uffe Østergård det uigennemskuelige forhold mellem religion og kultur/national identitet i Danmark og slår fast, at »Den særlige danske, religiøst begrundede nationalisme 
... først (blev) formuleret og systematiseret af ... N.F.S. Grundtvig i forbindelse med de konflikter, der førte til ... den borgerkrig i det danske monarki« (ibid., s. 358), som ifølge Østergård udgør den virkelige sandhed om det, der, inden for den danske, nationale mytologi, opfattes som Danmarks fredelige, og dermed lykkelige overgang til demokratiet i 1848, - en overgang, der netop derfor kan tjene som eksempel for andre dele af verden. Under overskriften Folkekirken og Europa - fri os fra mere »folkelighed" (ibid., s. 366) gør Uffe Østergård op med danskernes tildelen sig selv »rollen som bedrevidende småstat « (ibid., s. 366), en rolle, som har rod i Danmarks status som »ansvarsfri småstat mellem 1864 og 1991 « (ibid., s. 366). Uffe Østergård griber fat i indvandringen som et forhold, der vanskeliggør og problematiserer denne situation, ja, tvinger danskerne til revision af den folkelighed, han med Jørn Lund ser som knyttet til »en romantiserende forestilling om, hvordan tilværelsen var tidligere ( (Jørn Lund, i Om folkelighed, red. Haarder, 1995 op cit. ibid., s. 367):

De nye danskere er kommet for at blive, men selv om assimilationen skulle lykkes, bliver det nødvendigt at ændre på både monopolreligionen og det homogene folkelighedsbegreb der er blevet indarbejdet i den danske identitet. Begge er legitime resultater af en historie som man naturligvis skal stå ved som dansker. Men at vedgå arv og gæld er ikke det samme som stædig holden fast ved en kultur, der udsprang af en blodig borgerkrig i midten af sidste århundrede og nødvendigheden af at ligge lavt mens stærkere naboer udfoldede deres stormagtsaggressivitet« (ibid., s. 367).

Uffe Østergårds fremstillinger er alle præget af hans ønske om at forstå udviklingen, og dermed også forstå det folkelighedsbegreb, hvis utidssvarende kærne han mener at afdække. Han er i så henseende væsentligt mere afdæmpet end de skribenter, der i årene op imod årtusindskiftet har kritiseret Grundtvig i den danske dagspresse. Alligevel forekommer det ikke usandsynligt, at det er hans fokusering på den grundtvigske traditions betydning, der i sammenhæng med Grundtvigs selvfølgelige placering i dansk selvforståelse har afstedkommet de bestræbelser på at knytte til ved Grundtvig, som man i de seneste år har kunnet opleve inden for Dansk Folkeparti, bevægelsen Tidehverv og Den Danske Forening. Væsentligt i den sammenhæng er, at Østergårds tanker så at sige er slået igennem i de mest indflydelsesrige intellektuelle kredse i Danmark. I undervisningsministeriets tidsskrift Uddannelse, 5, 1999 giver etnolo- 
gen, dr. phil. Thomas Højrup udtryk for, at »En dansk identitet, der vil kunne skabes respekt om i det kommende århundredes verden, kræver en dannelsesproces, der bringer os fra en identitet som selvgod kulturnation til en identitet som selvrefleksiv statsvilje«. I Selve artiklens korpus skriver Højrup om Danmarks opbrud fra den tosprogede helstat til nationalstaten og »det konstitutionelle selvstyre«(Thomas Højrup, 'Dannelse og dansk identitet - livsformer og nationalitet', i Uddannelse, 5, 1999):

Den danske stats dannelsesrejse nåede i løbet af et halvt århundrede det, vi i dag kunne kalde for den jugoslaviske erfaring. Den danske nationalismes sprængning af monarkiets multinationale helstat adskiller sig ikke principielt fra den serbiske nationalismes sprængning af den jugoslaviske helstat i vor tid. I Danmark varede sejrens rus til nationalismens katastrofe i 1864 (ibid.).

Det er Højrups sigte at afdække en splittelse mellem embedsmandsstanden og den menige dansker, som fremkom efter 1864, hvor embedsmændene nødvendigvis måtte "gøre sig uafhængig af den nationale fundamentalisme« (ibid.). Inærværende sammenhæng er det væsentligt, at det opgør med dansk selvforståelse efter 1864, som bærer artiklen, også kan findes i sammenhænge, hvor Grundtvig direkte inddrages, således hos Bertel Haarder, der forsøger at balancere mellem en accept af den danske myte om det lille folk, der vinder indad, hvad det har tabt udad og skaber »den danske model« og en kritik af den danske selvopfattelse. Men selv om Haarder elsker Grundtvigs fædrelandssange, er det hans påstand, at den danske nationalisme er åndløs og overfladisk, og "skjuler sin frygtsomhed i selvgodhed " (Bertel Haarder, Den bløde kynisme, - og selvbedraget $i$ Tornerose-Danmark, København 1997, s. 152ff.). Hvor de to eksempler er typiske for mennesker, der befinder sig inden for den intellektuelle »mainstream « i Danmark, er billedet et andet hos det danske højres ideologer.

På mange måder er Uffe Østergård og hans position skydeskiven for Tidehvervsteologernes angreb. Angrebet sigter mod de strømninger i dansk kultur og forskning, hvor menneskerettighederne danner udgangspunkt for integration og europæisk samarbejde. Bestræbelserne på at knytte til ved Grundtvig kan man finde helt tilbage i de for Grundtvigreceptionen betydningsfulde år omkring $1992 \mathrm{i}$ Tidehverv, og forbindelserne til Dansk Folkeparti intensiveres og udbygges i de følgende $a^{28}$. Det er i så henseende væsentligt at få slået fast, at grundtvigianerne har 
andre fronter, når det gælder drøftelserne om Grundtvigs tanker og deres betydning for Danmark og danskhed, eksempelvis den kritik af Grundtvig, Søren Mørch har givet.

Voldsommere end Uffe Østergårds behandling af Grundtvig er således den kritik, der bliver Grundtvig til del i Odensehistorikeren, universitetslektor Søren Mørchs Den sidste Danmarkshistorie, hvis fremkomst i 1996 hensatte dele af den grundtvigske bevægelse i raseri og førte $P$. Engberg til at betegne værket som »en pubertetsagtig reaktion mod de grundtvigske forfædre« (Kristeligt Dagblad 17/9 1996) med tanke på Søren Mørchs slægtskab med Ernst Trier og Morten Pontop-

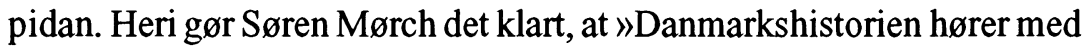
til det ideologiske gods, der er ved at blive pakket sammen« (Søren Mørch, Den sidste Danmarkshistorie, 75 fortcellinger af foedrelandets historie, København 1996, s. 13) og at der fra nu af kun kan blive fortalt "forskellige historier" (ibid., s. 13), samt at den, han fortæller, skal handle om, hvordan Danmark udviklede sig til en nationalstat. Værket fremstår som en delvis populærvidenskabelig fortælling, hvis personlige, engagerede tone kommer til udtryk $\mathrm{i}$ forfatterens velskrevne og respektløse bestræbelser på at rive tæppet væk under myten om Grundtvig og den grundtvigske tradition. I den forbindelse introducerer Mørch i sammenhæng med sin skildring af digterpræsten Kaj Munks kritik af det parlamentariske demokrati en sammenligning mellem Hitler og Grundtvig, der har afsat spor i andre tekster, hvor der lægges afstand til Grundtvig og den grundtvigske bevægelse:

Grundtvig var blandt meget andet også et tågehorn og en obscurantist. Det lå ham som bekendt ikke fjernt at betragte danskerne som Guds udvalgte folk, hjertefolket, og derfra og til at se ned på andre er der ikke noget spring, kun en lille glidning. Hvor befandt Kaj Munk sig, når han i en anden stor tale i 1940 en måned efter Olleruptalen afskrev Hitler til fordel for »den hvide races Gud, den levende Kristus «? Fra masser af højskolefolk er der utallige racistiske udtalelser, ... (ibid., s. 245).

Søren Mørchs sidste Danmarkshistorie ligger med sin »dybt personlige og nedgørende vurdering af Grundtvigs virke« (Finn Stendal Pedersen, 'N. F. S. Grundtvig og socialpolitikken i Den grundlovgivende Rigsforsamling i foråret 1849', i Historie, 1991, 1, s. 36) bag dele af den Grundtvig-kritik, der forekommer i dagspressen hen imod slutningen af 1990 'erne. Mørch har givetvis også spillet en rolle for det stadigt mere 
intense angreb på og livtag med Grundtvigs tanker, som universitetslektor, dr. phil. Hans Hauge gennemførte som medredaktør af den kirkelige grundtvigianismes blad Dansk Kirketidende, og som resulterede i bogen Den danske kirke nationalt betragtet, København $1998^{29}$. I dette værk glider indflydelsen fra Mørch sammen med påvirkninger fra Uffe Østergård, hvilket kommer til udtryk i Hauges dekonstruktive tilgang til den danske folkekirkes teologi, hvis binding til en grundvigsk forstået folkelighed Hauge finder utidssvarende. I stedet foreslår Hauge, hvad han kalder »en ny grundtvigsk revolution « (H. Hauge, Den danske kirke nationalt betragtet, København 1998, s. 128), dvs. en revolution, der løsner kirkens bånd til den homogene nationale kultur. Endnu er billedet i den danske offentlighed eller i dansk akademisk debat imidlertid ikke entydigt negativt.

IV Folkelighed, frihed og tolerance - Grundtvig-kritikken og Dansk Folkepartis brug af Grundtvig i årene omkring 1998.

Søren Mørchs og Uffe Østergårds værker udsendes i en tid, hvor den begyndende Grundtvig-kritik brydes med den traditionelle positive Grundtvig-reception, der i vidt omfang er blevet accepteret også af udlændinge med kendskab til Danmark. Endnu i årene omkring 1998 kan man møde det traditionelle billede af Grundtvig i det arbejde, der dette år blev resultatet af Det Danske Kulturministeriums konkurrence om det bedste udenlandske essay om nordisk identitet (Nordic Identity - seen from without, Danish Ministry of Cultural Affairs. København 2000). Vinderen, franskmanden Jean Francois Battail såvel som australieren Stanley Martin opfatter det grundtvigske folkelighedsbegreb som præget af en universalisme, der bl.a. har afstedkommet en positiv holdning til de danske jøder, ikke mindst $\mathrm{i}$ forbindelse med deres redning under Anden Verdenskrig (ibid., s. 6, 10, 11, 17, 21). Essaysamlingen afspejler daværende kulturminister Elsebeth Gerner Nielsens grundtvigsk motiverede interesse for folkelighedsbegrebet - ivrigt kritiseret af kulturdebattøren Carsten Jensen, (Carsten Jensen, 'Hvis jeg var kulturminister', Politiken 5/92000, og 'Farvel til Socialdemokratiet', Politiken 20/11 2001). Hvad der endnu hos Battail og Martin betragtes som nordiske kærneværdier, der kunne tjene som forbillede for nationer og kulturer verden over, betragtes i samme periode i stadigt større omfang inden for ledende kredse i den danske kultur- og samfundsdebat som en dødvægt fra fortiden, en arv, der bør tages op til revision på grund af 
dens manglende funktionsdygtighed i en moderne globaliseret og multikulturel verden. Den svenske kulturminister Marita Ulvskogs tiltro til, at netop folkelighedsbegrebet i kraft af dets universalistiske humanisme formår at danne udgangspunkt for integrationen af mennesker med en anden kulturel baggrund, - $\mathrm{i}$ analogi med begrebet »nydanskere« kaldet "nyboere « - står i grel modsætning til holdningen hos kulturdebattører som for eksempel Klaus Rothstein (Nordisk vardigrundlag og nordisk identitet, Det danske Kulturministerium, 1999, s. 9). Medens det officielle Danmark og Norden endnu kan hylde den grundtvigske folkelighed, er andre således på vej med uhørt skarpe angreb.

De voldsomste kritikere af Grundtvig har været lektor Jørn Arpe Munksgaard, der med sin kronik 'Nationalismen - to århundreders Pest', Jyllands-Posten 20/11 1997 tegnede et billede af både Grundtvig og den europæiske nationalisme som ensidigt negative fænomener, og skolebestyrer Jan Bunkenborg, der med sin 'Luft ud efter Grundtvig'kronik i Politiken d. 6/3 1999 indledte en længere debat. Bag Jørn Arpe Munksgaard (og Jan Bunkenborg?) aner man et engagement i romerskkatolsk kirkeliv, uden at der dermed her skal peges på, at et tilhørsforhold til denne kirke med nødvendighed fører til Grundtvig-kritik. Både Munksgaard og Bunkenborg drager paralleller mellem Grundtvig og den tyske nationalsocialisme. Det er betegnende for denne tidlige fase af Grundtvig-kritikken, at de to kronikker ikke primært tager sigte på indvandrerspørgsmålet, men fokuserer på, hvad der opfattes som den grundtvigske nationalisme og den grundtvigske oplysningstraditions lærdomsfjendtlighed ${ }^{30}$. Afgørende for nærværende sammenhæng, hvor folkelighedsbegrebet tolkes i sammenhæng med Grundtvigs tanker om social lighed, demokrati og frihed, er, at Bunkenborg tager sig på at dementere »myten om Grundtvig«, den myte, hvori han var »demokrat, social i sin tankegang og den lille mands beskytter « (ibid. $)^{31}$. Ligesom Søren Mørchs historieskrivning glimter frem i dele af Bunkenborgs materiale, hører man Mørchs fornævnte sammenligning som baggrund i følgende udtalelser, fremsat af Jan Bunkenborg, efter at han har "aflivet" den hyppige danske modstilling af nationalisme og den helt anderledes nationale folkelighed:

Hitlers 'filosofi' om det ariske menneske modsvares ganske af Grundtvigs opfattelse af det nordiske menneskes overlegenhed, og Grundtvig betragtede jøderne som et underlegent folk. Grundtvig har udtrykt sin ringeagt for det parlamentariske system, ... (Jan Bunkenborg, 'Luft ud efter Grundtvig', Politiken 6/3 1999). 
Bunkenborgs anliggende er at få »luget ud i det nationalromantiske arvegods « med det formål, at hans generation og dennes børn skal blive $\mathrm{i}$ stand til at »befinde sig godt « (ibid.) i den europæiske union. I årene, hvor hans kronik står at læse i det traditionelt kulturradikale dagblad, tages temaet Grundtvig og de danske jøder op gennem inddragelse af det materiale, der muligvis udgør baggrunden for Bunkenborgs ovenfor citerede bemærkning. Et afgørende skridt i bevægelsen hen imod det nuværende billede af Grundtvig som ensidigt fremmedfjendtlig har kulturskribenten Klaus Rothstein og (litteratur)historikeren Morten Thing således taget med deres fremdragelse af debatten mellem Grundtvig og den danske jøde, forfatteren Meir Aron Goldschmidt fra treårskrigens dage, dvs. fra 1848 til $1851^{32}$. M. A. Goldschmidt kæmpede i sit tidsskrift Nord og Syd for at bevare den danske helstat og $ø$ nskede, at den fremover skulle have karakter af en »Føderativstat « efter schweizisk mønster (M.A. Goldschmidt, 'Føderativstaten i Nord og Syd nr. 2, 1849), omfattende kongeriget Danmark og Slesvig-Holstein. Grundtvig ønskede en ren nationalstat og udviklede sig i løbet af treårskrigen fra at være tilhænger af en form for sindelagsgrænse til at fastholde floden Ejderen som grænse mellem Danmark og Tyskland. I forbindelse med diskussionerne mellem det national-liberale parti, tilhængerne af den gamle helstat og Grundtvig skrev Goldschmidt en artikel om nationalitetsbegrebet, hvori der forekom et opgør med Grundtvig (M.A. Goldschmidt, 'National' i Nord og Syd nr. 2, 1849). Angrebet foranledigede Grundtvig til et voldsomt udfald mod Goldschmidt, hvori han frakender Goldschmidt ret til at give sin mening til kende i danske anliggender. Selv om Grundtvig ikke anfægter Goldschmidts statsborgerskab i Danmark, er han for Grundtvig »folkelig talt, en Gioest iblandt os « og »bryder" "Giæstevenskabet og misbruger baade vort Fæderneland og Modersmaal« (N. F. S. Grundtvig, 'Svar paa Hr. Goldschmidts Angreb paa Danskheden' i Danskeren, II, Nr. 44, 1849, s. 690, 694). Klaus Rothstein fæstner sig ved, at Grundtvig således frakender Goldschmidt ret til at ytre sig i danske anliggender og fokuserer på Grundtvigs gentagne brug af gloserne »Fremmed « (ibid., s. 692) og »det Fremmede« (ibid. s. 697). Rothstein, der tilsyneladende ikke er klar over, at også Grundtvigs sociale sindelag er blevet betvivlet i forbindelse med bølgen af Grundtvig-kritik (se hertil s. nærv. art. s. $224 \mathrm{ff}$ ), skyder myten om Grundtvig som frisindets, dvs. som den danske tolerances fader ned, idet han skriver: 
Vi bærer hver især på en indre grundtvigianer, for når det kommer til stykket er vi alle i dette land rundet af den gamle digterpræst. Åbenbart er der ingen grænser for hvilket projekt eller hvilken idé, han kan spændes for. Både marxister og nationalister har raget med syvtallet $i$ versedyngerne $\mathrm{g}$ fundet belæg for netop deres sandheder, sågar new age-bølgen er skyllet ind over prædikener og poesier. Grundtvig gav os folkeoplysning, han gav os mund og mæle og tro uden tvivl, han er en af grundlovens fædre, på mange punkter forud for sin tid i tænkningen af det sociale samfund. Men han var også stridsmanden bag en national fundamentalisme, der i de senere år har fundet en alliancepartner på den yderste højrefløj, hvis politiske legitimitet søges i modviljen mod de fremmede. Grundtvig mente at Goldschmidt »folkelig talt er en Giæst iblandt os« og at det ikke tilkommer ham at diskutere danske forhold på samme måde som arvtagerne af Grundtvigs intolerante side i dag mener, at »de fremmede« ikke bare skal tilpasse, men under ét underkaste sig de danske normer« (Klaus Rothstein, 'Jeg vil lære jer at hade' i Kvinde på Dronning Louises Bro, København 2000, s. 62).

Ved siden af Rothsteins her citerede angreb på Grundtvig og den grundtvigske arv i dansk kultur har Morten Thing, som Rothstein af jødisk afstamning, angrebet Grundtvigs stillingtagen i debatten med Goldschmidt og anfører her, at Grundtvig ganske vist ikke som »raceteoretikerne senere i århundredet « er »optaget så meget af det biologiske«, men at han alligevel hylder »den samme irreduktible og væsensbundne forestilling om kulturens tradering" (Morten Thing, 'Løver og abekatte. Eller hvad er danskhed?' i Ud af det moderne, Den kritiske tanke anno 2000 , red. H. Ljungberg og E. Svendsen, København 2000, s. 47). Thing mener således at kunne kritisere Grundtvig for at fremføre en essentialistisk opfattelse af national kultur, og han påpeger i forlængelse af denne kritik, at det på grund af jødernes indoptagelse af kultur og "opblanding" (ibid., s. 51) med de folkeslag, de har boet iblandt, ikke giver mening »at identificere 'jøder'overalt med ét folk « (ibid. s. 51) ${ }^{33}$.

Klaus Rothsteins angreb på Grundtvigs manglende tolerance - et angreb, der ligesom Bunkenborgs sigter mod at punktere den danske Grundtvig-myte - har sammen med Morten Things arbejder haft en vis gennemslagskraft uden for landets grænser. Således har dr. phil. Ole Vind inddraget Grundtvig-Goldschmidt-debatten på konferencer i Sverige ('Grundtvig - nycklen till det danska?', Centrum för Danmarksstudier, Lunds Universitet, efteråret 2001; Grundtvig og folkeligheden, 
Nordens folkelige Akademi, foråret 2002) og også behandlet den i Danmarks Radios P1-udsendelse Agenda 20/1 2002) v. Klaus Birkholm. Endelig har Klaus Rothstein selv behandlet striden på Grundtviginstituttet på Göteborg Universitet efteråret 2000.

Samtidig med dette har den intensiverede politiske debat i forbindelse med regeringsskiftet i Danmark i efteråret 2001 også fået betydning for debatten om Grundtvigs arv. Hvor stærk Grundtvig-kritikken i den danske offentlighed er, - altid forbundet med anklagen for nationalisme - ses af det forhold, at han kritiseres i forbindelse med debatten om den danske holdning til indvandrerspørgsmålet. Således kunne man dagen efter det danske valg under overskriften Da Danskheden gav bagslag læse, at Dansk Folkepartis sejr skyldtes, at Danmark ikke er

... en beskeden lilleputnation, men snarere en småstat, der altid har drømt om at blive en kulturel stormagt, lige siden vi blev banket af tyskerne i 1864. N. F .S. Grundtvig og den danske andelsbevægelse har da også givet danskerne meget at være stolte af, men hele tiden har selvgodheden og selvforgudelsen ligget på lur. Grundtvigianismens forvandling fra universalisme til indgroet nationalisme har et stort ansvar for dette (Bjarke Møller, 'Da Danskheden gav bagslag', i Information, 21/11 2001).

I tiden derefter kunne man læse sociologen Peter Gundelachs parallelle vurdering, tilsyneladende stærkt inspireret af den svenske idéhistoriker Ola Fransons komparative analyse af dansk og svensk debat om de fremmede i lyset af Grundtvigs tanker. Ola Fransson har i artiklen 'Danska bönder och den svenska staten, i Ord och Bild nr. 4-5 1998, s. $98 \mathrm{ff}$. hævdet, at Grundtvigs begreber om folk og folkelighed har medført, at danskerne i modsætning til svenskerne lægger et kulturbegreb til grund for deres behandling af indvandrerspørgsmålet og på det grundlag præges af en aggressiv fremmedfjendtlighed. Gundelach fremhæver

to historiske fænomener, der har formet en særegen dansk identitet. Det ene er Grundtvig. Det andet nationens dannelse med territoriale grænser under stadig afhøvling af udenlandske krigsmagter,

- en proces, der har bevirket, at vi er blevet meget ens, - $\gg$ I modsætning til at have en national identitet, der skal omfatte mange forskellige grupper, så får vi en national identitet, som er beregnet på at fortolke en hel masse nederlag «. Gundelach udbygger sin redegørelse, - der i dette 
stykke nok er inspireret af Uffe Østergårds seneste værk - ved at fæstne sig ved, at "grundtvigianismen eller i hvert fald en del af den « bygger på den tanke, at det danske folk »i enestående grad « er »et udvalgt folk, fordi vi har et fælles sprog, en fælles historie og en fælles tro«, hvilket gør, at »det at være dansk « opleves som »noget helt særligt«. Gundelachs argumenter kan her være blevet udformet under inspiration fra Ole Vind, men mindst lige så afgørende er det med Ola Fransson beslægtede argument, at »Pointen er - både når vi taler om indvandrere og EU - at vi er tilbøjelige til at tale om det, som om det udelukkende handler om kultur« (ibid.). Heroverfor står ifølge Gundelach andre nationers opfattelse af "andre individer eller lande i politisk-økonomiske sammenhænge« (ibid.). En refleks af Grundtvig-kritikken ser man - formodentlig - i Lilian Munk Rosings kommentar i Information 22/3 2002. Symptomatisk er ligeledes forfatterinden Suzanne Brøggers ord:

Hvad udad tabes, må indad vindes. Grundtvig kommer ind i billedet, og han dyrker danskernes sjæl, og hele folkeligheden, lighedstanken med højskolerne og andelsbevægelserne făr vind i sejlene. Det er alt sammen smukke og rigtige tanker, men de har en skyggeside. Og det er måske først nu, vi opdager, hvad der egentlig gemmer sig i skyggen « (Katrine Marie Guldager, 'Jeg vil være en fm dame, Interview med Suzanne Brøgger, Information 27/4 2002).

I Weekendavisen har man i foråret og sommeren 2002 kunnet opleve en række angreb på Grundtvigs folkelighedsbegreb og politiske tænkning, gennemført bl.a. af førnævnte Klaus Rothstein, der med referencer til indvandrerdebatten og under eksplicit inddragelse af kulturradikalismen som idémæssig baggrund spørger, om der inden for det danske, kulturelle højre overhovedet findes nogle, der ikke uafladeligt taler om »folkelighed (Rothstein, Klaus, 'Tak højre!', Weekendavisen, 3-7/5 2002 og 'Et borgerligt frisind', Weekendavisen 5.-11/5 2002, P. Cini, 'Mytologik', Weekendavisen 3-7/5 2002)

Også i udlandet har disse synspunkter vundet genklang. Som et resultat af forårets førnævnte konference om det grundtvigske folkelighedsbegreb på Nordens Folkelige Akademi i Göteborg kunne man i Svenska Kyrkans Tidning 22, 30/5-5/6 2002 - meget sent i forhold til konferencen, $\mathrm{o}$ først publiceret efter debatten om fremmedfjendtlighed mellem Mona Sahlin og Bertel Haarder - læse et referat ved Axel W. Karlsson af Ole Vinds forelæsning, hvori det fremhæves, at danskerne af Grundtvig opfattes som Guds udvalgte folk, der for at fuldføre sin ver- 
denshistoriske mission må »bevara sitt språk och sin etnicitet ren«. Axel W. Karlsson gør rede for, hvorledes »begreppet folklighet « står centralt for Grundtvig, som ifølge Karlsson understreger, at denne »måste hållas etnisk ren«. Begivenheden giver et godt billede af, hvorledes Ole Vinds doktorafhandling om Grundtvigs historiefilosofi fra 1998 har virket - og virker - $\mathrm{i}$ både den danske o $\mathrm{g}$ den svenske offentlighed. OleVind sigter med sin bog mod at kritisere Fichte-påvirkningen i Grundtvigs forfatterskab, som han opfatter som et skæbnesvangert element i Grundtvigs tænkning, idet Grundtvigs deraf følgende fokusering på etnisk renhed og afstandtagen fra folkeblandinger for Vind tager form af, hvad han opfatter som Grundtvigs bibelsk-fundamentalistisk funderede skabelsesmyte. Svagt i Vinds disputats står hans af hermeneutik prægede bestræbelser på at knytte til ved Grundtvigs historiske bevidsthed, og det er da også overvejende hans Grundtvig-kritik, der har vundet genklang i offentligheden (Ole Vind, Grundtvigs historiefilosofi, København1998, s. 114ff. og s. $558 \mathrm{ff})^{34}$. Axel W. Karlsson sammenligner med afsæt i Ole Vinds synspunkter - og med eksplicit inddragelse af Grundtvig-Goldschmidtdebatten, som Ole Vind gjorde opmærksom på-Grundtvig og nazismen, idet han slår fast, at

Det är ufrånkomligt att termer från det tyska ideologiska trettiotalet kommer i tankarna ... Grundtvigs beskrivning av »folkligheten « har stora likheter med tankarna på en särskild tysk »Volkstum« (ibid.).

På baggrund af Ole Vinds mundtligt fremførte opfattelse af Grundtvig som værende imod folkeblandinger - og dermed ifølge Vind mod blandægteskaber - og ud fra sine egne ræsonnementer konkluderer Karlsson, at grundtvigianerne har overdrevet betydningen af det grundtvigske vekselvirkningsbegreb ${ }^{35}$. Karlsson har over for nærværende artikels forfatter oplyst, at han i forbindelse med sin research anskaffede sig den af Den danske Forening udsendte bog Grundtvig og nutidens kamp for Danmark, Århus 2000, forfattet af Peter Neerup Buhl. Karlssons anvendelse af Neerup Buhls bog som dokumentation for, at Grundtvig satte den »egoistiske« kærlighed til et menneskes familie og fædreland højere end den almindelige menneskekærlighed, kristent tolket som næstekærligheden, er et godt eksempel på samspillet mellem Grundtvig-kritikken og den højreorienterede Grundtvig-reception i disse år.

Peter Neerup Buhl har op gennem 1990'erne været skribent i bladet Tidehverv i den periode, hvor der var tætte bånd mellem denne bevægelse, Den danske Forening og Dansk Folkeparti ${ }^{36}$. I førnævnte bog spo- 
rer man da også denne særlige danske version af den dialektiske teologis skelnen mellem Gud og menneske, evigt og timeligt, en skelnen, der for Neerup Buhl som for Tidehverv betyder, at kristendommens holden mennesket fast på dets endelighed umuliggør enhver form for ideologisering, dvs. menneskets eget selvmægtige forsøg på gennem abstrakte idéer at skabe den fuldkommenhed, som alene hører himlen til. Muligvis hører man også Kaj Thanings indflydelse, når Neerup Buhl i sammenhæng hermed skriver, at det »ydermere« var Grundtvig »inderligt imod at bruge kristendommens bud på politiske forhold « (Peter Neerup Buhl, Grundtvig og nutidens kamp for Danmark, Århus 2000, s. 80). Skarpere og bedre i henseende til analyser er de arbejder om Grundtvig, som er forfattet af repræsentanter for det egentlige Tidehverv. Samtidig kan man her aflæse en skelnen mellem den form, der lader sig anvende i brede kredse, og form og indhold i de teologiske analyser i bevægelsens eget blad. Artiklerne i Tidehverv borer dybere end artiklerne i andre, beslægtede sammenhænge.

En »lettere« udgave af Tidehvervs Grundtvig-reception kan man således finde i artikler i Dansk Folkepartis regi. Man kan eksempelvis henvise til partiets udnævnelse af Grundtvig til "Årtusindets dansker" i partiorganet Dansk Folkeblad, nr. 6, 1999. Lederen, formodentlig forfattet af partiets pressesekretær, Søren Espersen, taler om »Danmark og kristendommen i skøn forening" som »en fuldstændig selvfølgelig tilstand « for Grundtvig, idet folkelighed og kristendom altså hos Grundtvig "smeltede sammen «. Espersen sigter mod at vise, at Grundtvig derved gør kristendommen nærværende, og han fremhæver, at Grundtvig "således« både er »universel og national«. Inde i bladet skriver Tidehvervs-teologen og præsten Søren Krarup om Grundtvig som

En dansker, der også efter årtusindskiftet vil kalde danskerne til at være, hvad de er (Søren Krarup, 'Årtusindets dansker', i Dansk Folkeblad nr. 6, 1999, s. 9).

Søren Espersens fremhævelse af, at kristendommen »tegner« de universelle aspekter i Grundtvigs forfatterskab, rammer utvivlsomt noget centralt i forfatterskabet. Det er imidlertid karakteristisk for udviklingen i Tidehvervs-bevægelsen, at dens seneste udspil i forbindelse med bestræbelserne på at knytte til ved Grundtvig i vidt omfang er båret af et ønske om at underbetone det universelle i forfatterskabet, ja, at vise, at den eneste form for universalitet, der lader sig udlede af Grundtvigs 
forfatterskab, er et udsagn om, at alle mennesker helt og fuldt er bestemt af deres folkelige tilhørsforhold til en partikulær kultur.

Dette udspil er forfattet af Søren Krarups fætter, Jesper Langballe, ligesom han præst og medlem afFolketinget for Dansk Folkeparti. Jesper Langballe har i juninummeret af bladet Tidehverv anklaget nutidens grundtvigianere for at svigte Grundtvig. I 'Månedens Essay' giver Langballe en skildring af, hvordan grundtvigianerne for ham har været tilhængere af et billede af Grundtvig, ifølge hvilket han repræsenterede nogle "anskuelser om frihed og folkelighed og livsoplysning " (Jesper Langballe, 'Månedens Essay', i Tidehverv Nr. 6, 76. årgang juni 2002, s. 111), der var præget af uigennemskuelighed og manglende bestemthed. Den manglende indholdsmæssige prægnans i disse begreber hang sammen med det forhold, at friheden var en frihed til alt, en frihed til at tro hvad som helst, og at folkelighedens indhold var social solidaritet, demokrati og tolerance. Grundtvigianernes billede af livsoplysningen indholdsbestemmer Jesper Langballe ikke, men af artiklen fremgår det, at han mener, grundtvigianerne forstår den på baggrund af en accept af menneskerettighedsidealerne fra den franske revolution. For Langballe er det sådan, at grundtvigianerne glemte eller i det mindste underbetonede den »nationalistiske « side af Grundtvig, det forhold, at der for Grundtvig var tale om netop Danmarks frihed, at folkeligheden var lig danskernes nationale samhørighed og at livsoplysningen for Grundtvig var oplysning af den danske folkeånd, som den fandtes i de nordiske myter og i nutidens kærlighed til fædrelandet. Jesper Langballe fortsætter med at fortælle, hvor dette Grundtvig-billede er kommet fra: det stammer fra Kaj Thanings hævdelse af, at Grundtvig i 1832 sætter vandtætte skotter mellem kristendom og menneskeliv. Når det er tilfældet, kan man uden videre fylde folkeligheden ud med alskens ideologi, og altså også med den menneskerettighedstænkning, som Langballe er en svoren modstander af. For Langballe udgør den grundtvigske historie efter Thaning en lang deroute, en stadig læggen afstand til Grundtvig, som for ham kulminerer med artiklens anledning: et indslag i radioavisen, hvor højskolernes sekretariatschef, Erik Lindsø, gør rede for højskolernes ønske om at bidrage til integrationen af indvandrere og i den sammenhæng ønsker både Højskolesangbogen og »den nationalistiske side af Grundtvig« fjernet fra højskolernes undervisning. Langballes billede af Grundtvig har som udgangspunkt den grundantagelse, at Grundtvig i sit virke som menneske $\mathrm{i}$ en given sammenhæng alene havde Danmark og danskernes liv i tankerne: 
For Grundtvig var Danmarks beståen bestandigt det ene jordiske mål, og alt andet var tidsbetingede midler, der kunne skiftes ud, når målet krævede det (J. Langballe, 'Månedens essay' i Tidehverv, juni 2002, s. 111).

Hertil kommer, at Grundtvig ifølge Langballe er »en uforsonlig modstander af de menneskerettighedsidealer, som den franske revolution hylder «.

Langballe gør rede for Grundtvigs sigte gennem inddragelse af citater fra Grundtvigs tidsskrift Danskeren I-IV, 1848-1851. Han fokuserer her på Grundtvigs polemik mod enhver tale om en valmindelig MenneskeKiærlighed«. Med det som udgangspunkt skildrer han, hvorledes Grundtvig modstiller folket og staten, en modstilling, der udmønter sig i Grundtvigs kritik af det ufolkelige begreb konstitution og i Grundtvigs afvisning af statens tvungne fattigpleje - en fattigpleje, der for Grundtvig er udtryk for en overtro på statens evne til at kunne udbedre alle forhold, gøre alle fattige rige såvel som alle mennesker gode. Og efter på denne baggrund at have modstillet Grundtvig og, hvad han under påvirkning fra Fonsmark kalder »nutidens socialdemokratiske grundtvigianer « (ibid., s. 112), bevæger Jesper Langballe sig til Grundtvigs opgør med danskernes falske beskedenhed, den, der ifølge Grundtvig gør, at danskere ind imellem foretrækker det fremmede frem for det, de skal holde af, eget sprog, egne ordsprog og i det hele egne traditioner. Endvidere gør Langballe rede for, at Grundtvig efter hans opfattelse også efter 1848 er tilhænger af en form for enevælde, der ved sin side har en rådgivende folkeforsamling, og med Grundtvigs kamp for den uindskrænkede valgret som mellemled bevæger han sig ind i en redegørelse for Grundtvigs syn på Danmarks forsvar. Her møder læseren for første gang i artiklen en kritik af Grundtvig. Langballe kan ikke forlige sig med Grundtvigs afvisning af tvungen værnepligt, dvs. Grundtvigs fremhævelse af frihedens og frivillighedens betydning for ægte fædrelandskærlighed. For Langballe er det afgørende, at ikke kærlighed, men lov og tvang er bærende i virkelighedens verden. $\mathrm{Og}$ han gør i den sammenhæng rede for, at grundtvigianernes omtolkning af Grundtvigs konkret forståede folkelighed til udtryk for almindelig humanisme i oplysningstidens og modernitetens kølvand netop knytter til ved dette sværmeriske islæt i Grundtvigs livsforståelse.

Jesper Langballes fremstilling af Grundtvigs tanker i treårskrigens og Danskerens dage hviler på en omfattende læsning i hele forfatterskabet 
og er et langt stykke hen ad vejen god Grundtvig-tolkning. Med rette gør Langballe rede for, at Grundtvig modstiller begreberne folk og stat. $\mathrm{Og}$ han har god støtte $\mathrm{i}$ tekstmaterialet, når han peger på Grundtvigs afvisning af en almindelig, abstrakt, humanistisk menneskekærlighed, der ikke tager hensyn til den konkrete folkelighed.

Imidlertid viser det sig undervejs, at Langballe har store vanskeligheder med væsentlige sider af Grundtvigs univers. For at "rredde» Grundtvig indfører han en lang og spændende analyse af Grundtvigs digt Paaske-Liljen, der sigter mod at vise, at Grundtvig som en god dialektisk teolog er bevidst om forskellen på himmel og jord, menneske og Gud. Langballe tolker Grundtvigs folkelighedsbegreb ud fra sin forståelse af Det Ny Testamentes brug af jordiske forhold som lignelser eller analogier på den himmelske virkelighed. Det er her afgørende for Langballe, at

netop som et henvisende tegn på det himmelske er det jordiske afskåret fra at bestemme sit eget mål eller indhold. Danskheden skal ikke definere sig selv som en særlig måde at være dansk på. Danskheden er - uden forklaring - til på forhånd (ibid. s. 118).

Med ordet dialektik, der her i forlængelse af Karl Barth har teologisk betydning, karakteriserer Jesper Langballe det forhold, at det jordiske, netop ved at være billede på det himmelske, holdes fast i sin jordiskhed, sin konkrete virkelighed, "mennesket selv i dets folkeligt historiske eksistens « (ibid. 118). Dialektik skal i den sammenhæng forstås sådan, at det jordiske både "betyder" det himmelske og samtidig er noget ganske andet end dette - der er tale om to hinanden modsat rettede påstande, hvis konflikt bunder i det forhold, at Guds virkelighed altid transcenderer eller overskrider den menneskelige virkelighed. Dialektikken er en »dialektik mellem saga og evangeliet« (ibid., 124). Der er tale om

... den evangeliets instans, som gør det timelige timeligt, og som hvert øjeblik holder det timelige på plads på jorden og giver mennesket et ganske bestemt og konkret sted at være (ibid., 126).

For Langballe er det væsentligt at slå fast, at det jordiske for Grundtvig er jordisk, er menneskeligt, og at det derfor er "Synderens naturlige selvkærlighed « (ibid., 119), som evangeliet tager i sin tjeneste. Og det er vigtigt for Langballe, at Grundtvig - når han ikke vrøvler, hvilket ind 
imellem sker - fastholder denne selvkærlighed i dens »egoistiske" konkretion, den selvkærlighed, der jo netop er den nationale folkelige kærligheds grundlag.

For Langballe er Grundtvig bedst, når han kritiserer den moderne tids "republikanske utopisme« (ibid., 119), eller når han, i ordets bedste betydning, på enfoldig vis blot lever i sin konkrete, givne virkelighed, dvs. i sin danske virkelighed ud fra og gennem evangeliets forkyndelse. Meget i artikelen peger på, at Grundtvig for Langballe er bedst i sine yngre år, i Danne-Virke-tiden fra 1816 til 1819, dvs. før 1832, hvor Grundtvig forfatter Nordens Mytologi, samt i sine senere år, hvor han går ind i sin samtids politik for at kæmpe for danskhedens sag. For Langballe repræsenterer »Grundtvigs historiske udviklingslære« (ibid., 120) en fase i forfatterskabet, hvor

... Grundtvig var blevet noget af en udviklings-optimist, der objektiverede sit historiske anliggende i et universelt verdensforløb i stedet for bare at være sig selv som kristen og dansk her og nu (ibid., 120).

Bag Jesper Langballes kritik af Grundtvigs 1832-position hører man Ole Vinds store bog om Grundtvigs historiefilosofi, som citeres i det næstfølgende. Men det er også i 1832, Grundtvig skelner mellem tro og anskuelse, den skelnen, Thaning knytter til ved, og som for Langballe bliver et »tveægget sværd", der rammer Grundtvig selv. Det er ikke usandsynligt, at Langballe her er påvirket af den Grundtvig-kritik, som man møder i Knud Riis' monografi, Højskolens Religion, Vejle 1998. Riis griber på baggrund af sin egen dialektisk-teologiske position fat $\mathrm{i}$, hvad der hos Grundtvig fører til menneskets religiøsitet og ikke til kristendom. I en skarp analyse af, at det er menneskets spørgen efter Gud, der for Grundtvig udgør, hvad der er »fællesmenneskeligt « (ibid., s. 121), bevæger Langballe sig ind i en drøftelse af, hvorvidt Grundtvig i 1832 har åbnet for »en folkelighedsidealisme, løsrevet fra evangeliet« (ibid., s. 121). For Langballe er dette under alle omstændigheder tilfældet i Thanings Grundtvigtolkning. Imidlertid fastholder Langballe, at Grundtvig trods sit forsøg på at komme samtidens idealistiske intellektuelle i møde ikke forfalder til et »universelt systemmageri« (ibid., s. 121) og ikke taler kvantitativt om menneskeheden, men om mennesket konkret forståt i dets danske, folkelige virkelighed: 
Det er danskens, eller det er nordboens syn på - naturligvis ikke, hvad det er at være dansk eller nordbo, men - hvad det er at være menneske (ibid., s. 121).

Langballes ord kunne her opfattes således, at han trods alt mener at kunne finde en bevidsthed hos Grundtvig om, at der kan fremsættes universelle udsagn om det at være menneske. Men Langballes tolkning dementerer en sådan forståelse. For Langballe er det eneste universelle udsagn, der kan fremsættes om mennesket, udsagnet om, at det altid er menneske indenfor konkrete, partikulære sammenhænge, idet der ikke gives, hvad Grundtvig betegnede som en »almindelig Menneske-Kiærlighed «, det eneste »fællesmenneskelige« udsagn, der kan fremsættes, er udsagnet om,

... at der intet universalhistorisk er i programatisk forstand (ibid., s. 126).

Langballes Grundtvigtolkning berører her den grundtvigske livsoplysning, som i Danmark opfattes som kernen i den folkeoplysningstradition, der er udgået fra Grundtvig. Det er bemærkelsesværdigt, at Langballe i sine analyser bestræber sig på at lægge afstand til Kaj Thaning ved netop at sige, at livsoplysningen kun er sand, hvis den på dialektisk-teologisk vis holdes sammen med evangeliet. For Langballe er den oplysningsmæssige front her ikke Grundtvigs modstandere, men grundtvigianerne. Dette synes at korrespondere med, at han ukritisk accepterer Grundtvigs modstand mod retten til offentlig forsørgelse i grundloven.

$V$ Folkelighed, social lighed og demokrati - kritikken af myten om Grundtvig som den danske velfordsstats fader.

Ovenfor er der givet en fremstilling af Grundtvigs stilling i nutidig dansk politisk og kulturdebat. Udgangspunktet var her Grundtvigs folkelighedsbegreb, og konteksten udgjordes af diskussionerne om national identitet. Polariseringen i det danske samfund, hvor en indvandrer- og EU-kritisk fløj står over for, hvad andre opfatter som bestræbelser på at bringe det danske samfund på højde med den europæiske udvikling, er, som det fremgik, i vidt omfang knyttet sammen med en diskussion af menneskerettighederne og deres status som et muligt grundlag for politik 
og samfundsliv. Inden for den indflydelsesrige Tidehvervs-bevægelse knyttes Grundtvig-begejstringen sammen med en afstandtagen til menneskerettighederne som grundlag og et ønske om at gøre etniciteten, og dermed tolkningen af den grundtvigske folkelighed som lig menneskets "givne«, konkrete livsvilkår, til udgangspunktet for dansk politik og samfundsliv. I forbindelse med Jesper Langballes Grundtvigtolkning strejfedes Grundtvigs stillingtagen til det sociale spørgsmål. Ligesom i analysen af Frederik Borgbjergs Grundtvigtolkning blev det undervejs klart, at den Grundtvig-myte, som Jan Bunkenborg, Klaus Rothstein og andre ønsker at »afmontere«, i vidt omfang præges af en identifikation af Grundtvig og det danske, demokratiske velfærdssamfund. Denne antagelse støtter sig oftest på dét citat fra Grundtvigs sang Langt højere Bjerge eller Danmarks Trøst, der som før nævnt nok er det kendteste af Grundtvigs ordsprogsagtige formuleringer, ordene om at »da har i Rigdom vi drevet det vidt/Naar faa har for meget, og færre for lidt« (N. F. S. Grundtvig, 'Danmarks Trøst', i Poetiske Skrifter, udg. af Svend Grundtvig og Georg Christensen, I-IX, V, s. 64). I en længere årrække har den socialdemokratiske politiker og historiker, cand. polit. Henning Tjørnehøj, i den danske offentlighed bestræbt sig på at afdække falskheden i dette billede, idet han først og fremmest griber fat $\mathrm{i}$ Grundtvigs forsøg på at bremse den danske grundlovs paragraf om offentlig understøttelse til den, der ikke er i stand til at forsørge sig og sine, og indføjer dette i et generelt angreb på den grundtvigske bondestand i Danmark, som for ham at se har bestræbt sig på at holde husmænd og landarbejdere ude fra den sociale velstand, som blev opnået $\mathrm{i}$ anden halvdel af det 19. århundrede, et angreb, der skæmmes af Tjørnehøjs - bevidste? - hævdelse af, at der ikke før 1915 fandtes et landarbejderforbund i Danmark. Tjørnehøj glemmer Fernando Linderbergs grundtvigske landarbejderorganisation (se Claus Bjørn, 'Fernando Linderberg', i Dansk biografisk Leksikon, 9, København 1981, s. 67f. og A. Pedersen, 'Grundtvigianismens forhold til det sociale spørgsmål fra 1855-1903, med særligt henblik på Fernando Linderberg og hans forhold til Socialdemokratiet', i Det grundtvigske bondemiljø, red. J. Holmgaard, Odense 1981, s. 153ff. (H. Tjørnehøj, 'Grundtvig og folkeligheden' kronik i Jyllands-Posten 11/10 2000). Med baggrund i Grundtvigs modstand mod den førnævnte fattiglov konkluderer Tjørnehøj i afsnittet "Den socialt reaktioncere Grundtvig" i sin bog om Louis Pio om »den danske 'folkeligheds' åndelige fader« (H. Tjørnehøj, Louis Pio - folkevcekkeren, København1992, s. 21f.), at 
Grundtvig skal mindes for sin kamp for åndsfrihed, kampen mod 'den sorte skole'(latinskolen) og for sit store 'sang-værk', hvori han inderligt, enkelt og stadigt bevægende har digtet om sine landsmænds og -kvinders forhold til hinanden, deres børn, deres fædreland og modersmål. Han var en sjældent god kender af det danske sprog. Men socialt var Grundtvig yderst reaktionær. Og det er historieforfalskning af rang, når han - selv af venstrefløjskulturister - gøres til det danske demokratis og velfærdssamfunds åndelige eller folkelige fader (ibid., s. 23).

Henning Tjørnehøjs kritik af Grundtvig kan med fordel holdes sammen med Frederik Borgbjergs begejstrede, socialdemokratiske fortolkning af Grundtvigs hovedmotiver 59 år tidligere. I vidt omfang deler de to socialdemokrater udgangspunkt, idet begge er interesserede i, hvad Tjørnehøj i tråd med nærværende artikels systematisering af dansk identitets "vandårer" (s.185ff) præcist betegner »den sociale frihed eller lighed" (ibid., s. 22), dét, Hartvig Frisch som omtalt s. 181 kalder for »det sociale demokrati«. Væsentligt er det, at Tjørnehøj, der på sin vis fastholder billedet af Grundtvig som den, der »sætter ord på « dansk identitet eller selvforståelse, mener at rive tæppet væk under Borgbjergs sammenkædning af Grundtvig, social lighed og parlamentarisk demokrati ${ }^{37}$.

I sin hævdelse af, at Grundtvig ikke var demokrat, vinder Tjørnehøj hen imod 1990'ernes midte tilslutning fra flere forskere og kulturdebattører. Ingen har skarpere og bedre behandlet Grundtvigs syn på statens styre end Tine Damsholt (Tine Damsholt, Troen på folkeviljen; analyse af en tradition $i$ dansk demokratiopfattelse $i$ de sidste 200 år, Vejle 1994), men også Grundtvig-forskeren Ole Vind har taget emnet op og gjort det klart, at omend Grundtvig »i 1848« »ikke« var »imod folkerepræsentationen som sådan« (Ole Vind, 'Grundtvig og demokratiet' i Højskolebladet 11, 1998, s. 8), afviste han dog ud fra sin sympati for tanken om samspillet mellem en folkeforsamling og en »enevældig konge" (ibid., s. 8) det demokrati, som den danske grundlov skabte, det repræsentative demokrati. Ole Vinds bedømmelse af Grundtvig er i spørgsmålet om konstitution mere nuanceret og langt mere forstående over for Grundtvigs anliggende end Henning Tjørnehøjs. I en dansk sammenhæng har interessen imidlertid samlet sig om Tjørnehøjs opfattelse af Grundtvigs socialt reaktionære synspunkter, det forhold, at Grundtvig ifølge Tjørnehøj kun ville give offentlig hjælp til »fattige gamle, syge og børn«, medens »alle andre, der kom i materiel nød, 
skulle ... have klaret sig selv« (H., Tjørnehøj, Louis Pio - folkevœkkeren, København 1992, s. 21). Henning Tjørnehøj får i den danske grundlovs jubilæumsår 1999 følgeskab af en grundigt arbejdende, yngre historiker, hvis fremstilling og analyser står centralt $\mathrm{i}$ den akademisk udformede Grundtvig-kritik i årene omkring 1998.

Odense-historikeren Finn Stendal Pedersen, hvis beskæftigelse med dansk landbohistorie af Steen Busck er blevet karakteriseret som et led i den tradition, der med Thorkild Kjærgaard er kritisk over for "gårdmandssønnernes" udgave af landbohistorien (Steen Busck, 'Friedlev Skrubbeltrang og landbohistorien', i Mangfoldighedens Pris, Dansk Faghistorie - en status. Den jyske historiker, 1997, nr. 75-76, s. 69ff), dvs. den retning, der ud fra et studium i landarbejderes og husmænds kår er kritiske over for det officielle billede af nyere dansk historie som båret af den danske gårdmandsstands emancipation efter bondefrigørelsen $\mathrm{i}$ slutningen af det 18, århundrede, skriver således i afhandlingen 'N. F. S. Grundtvig og socialpolitikken i Den grundlovgivende Rigsforsamling i foråret 1849', Historie 1999, 1, s. 32ff. om Grundtvigs kamp mod forsørgelsesparagraffen i grundloven ${ }^{38}$. Afhandlingen er præget af en grundighed og vilje til at tolke Grundtvig ud fra dennes kristent-kulturelle helhedsunivers, idet Stendal Pedersen følger Kaj Thaning i spørgsmålet om Grundtvigs adskillelse af kristendom og menneskeliv i 1832. Stendal Pedersen forsøger i denne sammenhæng at omsætte Thanings teologisk formulerede Grundtvigtolkning i en profanhistorisk form. Denne omsætning medfører en række vidtgående konklusioner, der har relevans for Grundtvigs stillingtagen til det sociale spørgsmål på den måde, at Grundtvigs adskillelse af menneskeliv og kristendom og hans hævdelse af »Menneske først«-princippet for Stendal Pedersen medfører, at alene menneskets væren »i stand til at kommunikere og analysere livet« er en forudsætning for modtagelse af kristendommen, ikke det forhold, at mennesket forud for dets modtagelse af kristendommen har gennemgået »en vis kulturel og social udvikling " (ibid., s. 38). Stendal Pedersens argumentation er her en smule uigennemskuelig, men med fare for fejlfortolkning kan hans indoptagelse af Thaning forstås i forlængelse af Henning Tjørnehøjs angreb på Grundtvig for at mangle forståelse for de fysisk-materielle sider af menneskelivet $\mathrm{og}$ for en deraf følgende favorisering af oplysning fremfor social velstand. I sin grundige, veldokumenterede fremstilling af debatterne i Rigsforsamlingen bevæger Stendal Pedersen sig frem til introduktionen af sin »helt«, præsten C. H. Visby fra Vor Frelsers Kirke, der i sit indlæg betonede, at forsørgelsesretten 
netop er den fattiges »Ret« (ibid., s. 53), uden at Stendal Pedersen tematiserer den i fortid og nutid så væsentlige debat om menneskerettigheder, der i denne sammenhæng synes nærliggende, og som er afgørende for forståelsen af C. H. Visbys motiver (se hertil Michael Bregnsbo, Samfundsorden og statsmagt set fra Proedikestolen. Danske prosters deltagelse $i$ den offentlige opinionsdannelse vedrørende samfundsordenen og statsmagten 1750-1848 belyst ved trykte proedikener. En politisk-idéhistorisk undersøgelse, København 1997, s. 194). Efter under overskriften Gronserne for Grundtvigs humanisme at have henvist til den økonomiske teoretiker David Ricardo (1772-1823) som Grundtvigs inspirationskilde introducerer Stendal Pedersen yderligere utilitaristernes opfattelse af, at det er »religionens vigtigste opgave at løfte de underste klasser fysisk og moralsk « (ibid., s. 57), som et muligt, samtidigt alternativ til Grundtvigs holdning. Stendal Pedersen kritiserer Grundtvig for at mangle indsigt $i$ den sociale fremgangs nødvendighed for de fattiges »tilegnelse af den kristne tro« (ibid., s. 57) og slår i sin konklusion fast, at Grundtvigs »betydning « $\mathrm{i}$ »Dansk kultur og historie« er »en betydning på såvel ondt som godt « (ibid., s. 57). Han fastholder, at det »i dette lys « er »ganske ironisk, at Grundtvig i begyndelsen af 1970'erne blev politisk profet for en række af de venstreorienterede og anarkistisk prægede ungdomsoprørere« (ibid., s. 57), og han peger på rimeligheden af at koble Grundtvig sammen med det liberale parti Venstres bestræbelser på at arbejde hen imod en nyliberalistisk minimalstat.

Finn Stendal Pedersen skyder således myten om Grundtvig som ideologisk inspiration bag udformningen af den danske velfærdsstat i sænk og trækker en linje fra »Estrups og dermed Højres positive sociallovgivning " (ibid., 58) til det danske Socialdemokratis og »De radikales opbygning af velfærdsstaten « (ibid., 58 $)^{39}$. Relativt uanfægtet i artiklen står det grundtvigske begreb om, hvad der i den kirkelige nygrundtvigianismes og folkelige grundtvigianismes hovedorgan Højskolebladets første år betegnedes som ikke folkeoplysning, men netop folkelig Oplysning (Højskolebladet, 1 Aarg. 1, 1876), omend Stendal Pedersen netop kritiserer Grundtvig for at prioritere dette fremfor menneskets sociale fremgang. Omtrent samtidig med Stendal Pedersens analyse tages der imidlertid skridt til at rette skytset også mod denne del af den grundtvigske arv. 
Kritikken af den grundtvigske folkeoplysning har mange og væsentlige tråde til opgøret med folkelighedsbegrebet. I de sammenhænge, hvor Grundtvigs oplysningstanker sættes på anklagebænken, virker det, som om en strategisk, men i et vist omfang også oprigtig tilknytning til de indflydelsesrige bestræbelser på at bryde med det nationale paradigme $\mathrm{i}$ dansk kultur og politik virker befordrende for den offentlige omtale af et givet emne. Dette har været stærkt fremtrædende i forbindelse med skolehistorikeren Søren Ehlers' doktorafhandling Ungdomsliv. Studier $i$ den folkeoplysende virksomhed for unge i Danmark 1900-1925, København 1998. Ehlers retter dødsstødet mod den grundtvigske folkehøjskole og oplysningstradition ved i forlængelse af sit disputatsarbejde at fremhæve, at

Der findes ikke nogen dansk model for folkeoplysning. Idéerne, som lå bag højskolerne, oplysningsforbundene og spejderbevægelsen, er ikke danske. De er hentet alle mulige steder fra ... ('Myten om Højskolen', Interview med Søren Ehlers, Morten Mikkelsen i Kristeligt Dagblad 4/1 2000).

Søren Ehlers vurderer på baggrund af sine studier i det 20. århundredes første fjerdedel, at

grundtvigianere gennem hele århundredet har formået at skabe en myte om højskolen som en ganske særlig dansk skole, som var livsnødvendig for nationen og derfor måtte have et fortrin (ibid)

et synspunkt, han underbygger med den opfattelse, at »det eneste særlige ved den danske tradition « ikke er »højskolen eller folkeoplysning, men det faktum, at statsmagten gik ind med aktiv støtte på dette område« (Aarhus Stifttidende 10/01 2000), »det eneste særlige ved det danske folkeoplysende og frivillige arbejde er, at det offentlige giver tilskud « ('Myten om Højskolen', Interview med Søren Ehlers, Morten Mikkelsen i Kristeligt Dagblad 4/1 2000). Det er karakteristisk for Ehlers's promovering af sin forskning, at de her citerede synspunkter fandt vej til næsten hele den danske presse i en kombination med hans kritik af folkelighedsbegrebet, som for Ehlers udgør »noget af det mest dunkle, 
der findes på dansk « (Politiken, 15/1 2000), idet han dog fremhæver, at det "på Grundtvigs tid« var »synonymt med det nationale« $(\text { ibid. })^{40}$.

Søren Ehlers's bredside mod den nationale dannelsestradition er et eksempel på, at forskere griber direkte ind i debatten mellem essentialister og konstruktivister, som ovenfor blev skildret gennem Tine Damsholts udtalelser. Den applikation af den internationale nationalismeforskning på danske og nordiske forhold, som Uffe Østergård siden 1984 har gennemført, indgår her i forening med en kritik af den danske undervisningstradition. Ehlers retter dødsstødet mod den grundtvigske oplysningstraditions højborg, den danske folkehøjskole. En yngre forsker, Claus Haas, som Ehlers fra Danmarks Pædagogiske Universitet, har på det seneste gennemført en lignende kritik af den nationale ideologi, han opfatter som baggrunden for skolernes danskundervisning. Et engelsksproget citat make peasants into Danes, midt i hans kronik i Politiken sandsynliggør en indflydelse fra Uffe Østergård, og uden at Grundtvigs navn nævnes, inddrages den grundtvigske retning således i hans analyser, der sigter mod at demonstrere, at den nationale farve $\mathrm{i}$ børneskolens undervisning udgør den påvirkningsmæssige baggrund for den nuværende danske indvandrerpolitik (Claus Haas, Kronik i Politiken 8/8 2002, se U. Østergaard, Peasants and Danes. Danish National Identity and Political Culture, Aarhus 1990). Frederik Stjernfeldts anklage mod Grundtvigs folkelighedsbegreb for at vanskeliggøre et højt niveau i intellektuelle debatter i Danmark falder i tråd med disse angreb på den danske dannelsestradition (Adam Holm, 'Konkrete intellektuelle - ikke utopiske tågehorn', interview med Fr. Stjernfelt, Politiken 15/12 2001). En distanceret holdning til opfattelsen af højskolerne som Grundtvigs bidrag til ॥verdenspædagogikken« kan man møde hos rektoren for Danmarks Pædagogiske Universitet, professor, dr. phil. Lars Henrik Schmidt, der giver udtryk for den opfattelse, at Grundtvig sigtede mod en »realskole« med »eksamensbevis« ('Internatet er højskolernes bidrag til verdenspædagogikken', Interview m. Lars-Henrik Schmidt, Højskolebladet 9,2002 , s. 11) fremfor mod den af nationalromantikken prægede højskoles mål som dét »at gøre bønder til danskere« (ibid., s. 8). Helt afgørende er det, at kritikken af den grundtvigske arv er nået helt ind i højskolens verden og der har vundet genklang hos adskillige af dens bærende kræfter.

Situationen i Folkehøjskolen er den, at medens man for få år siden diskuterede daværende højskoleforstander Ole Jensens anklage mod højskolen for at arbejde på baggrund af en "Grundtvig light«-ideologi 
(Ole Jensen, 'Grundtvig light. Højskolen pynter sig med lånte fjer'. Aarhus Stiftstidende 3/12 1996), diskuteres hverken daværende højskoleforstander Morten Kvists højskolemanifest fra 1996 eller det forsøg på at fastholde en grundtvigsk arv i Folkehøjskolen, som udmøntede sig i Højskolemanifest 2000 (Morten Kvist, 'I anledning af Højskolemanifest 2000', Højskolebladet 125. årg., 33, 2000. I 1998 nedsattes et højskoleudvalg, hvis opgave har været at undersøge, hvordan »den bestående lovgivning kunne ændres for at fremme den danske folkehøjskoles fortsatte muligheder for folkelig oplysning og demokrati« (Kurt Finsten, Information 10/11 1999). I forbindelse med udvalgets rapport fik Grundtvig-kritikken inden for højskolen stemme i højskoleforstander Kurt Finstens karakteristik af rapporten som et »ideologisk remix af en række af højskolebevægelsens gamle travere«, - han navngiver i dagbladet Information selv disse »Livsoplysning«, »at oplive og oplyse«, »det folkelige« og »det historisk-poetiske, Nordens Mytologi og Skolen for Livet «, sammenfattet til »livet og det folkelige og Grundtvig « (ibid.). Finsten fortsætter med at gøre rede for daværende redaktør af Højskolebladet Niels Højlunds opbakning bag rapporten, idet Højlund i Højskolebladet modstiller det akademiske dannelsesideal og det dannelsesideal, der er højskolens, og som kommer til udtryk i højskolens "gamle kernefag historie, poesi, filosofi, samfundsfag etc." (ibid.). At disse »almene dannelsesfag « skal dominere i forhold til de specifikke fag, der ifølge rapporten højst må fylde halvdelen af en højskoleelevs tid, er for Finsten udtryk for »ren fundamentalisme«. I den sammenhæng vender han den traditionelle folkehøjskoles opfattelse om, idet han slår fast, at "problemet « ikke er samfundets manglende forståelse af den traditionelle højskoles værdier, men derimod »at højskolen ikke forstår omverdenen « (ibid.). Finsten kæder i den sammenhæng højskolens »kunstig(e) skel mellem det faglige og det almene« sammen med en national dannelsestradition:

Det er på tide, at højskolebevægelsen begynder at se fremad ... Hvad om man for en gangs skyld rykkede lidt og dristede sig til at diskutere højskolens rødder. Hele det nationalromantiske arvegods fra midten af forrige århundrede. Hvad om man droppede al den nationalisme og begyndte at interessere sig for noget så nutidigt som den globale udfordring. I et opgør med den latente nationalisme, som vi for tiden oplever hos Pia Kjærsgaard og Mogens Glistrup og Thorkild Simonsen og alle deres meningsfæller (ibid). 
Efter Niels Højlunds afgang som redaktør udkom Højskolebladet efter en kort pause med ny, provisorisk redaktion, inden man ansatte Jonas Kuld Ratje, der i skrivende stund igen er blevet afløst af Niels Elberling og Laust Riis-Søndergaard. I det første nummer af den nye årgang bragtes et interview med Kurt Finsten under overskriften 'Lad Grundtvig slappe lidt af' (Højskolebladet, 1, 2002, s. 9ff.). Heri gør Finsten rede for, at den nationale linje i Grundtvigs forfatterskab misbruges af nynationalisterne, og at det først og fremmest er Grundtvigs »Frihedstanker« der i dag kan finde anvendelse i folkehøjskolen, idet friheden er grundvilkåret for mødet mellem mennesker »i tillid« (ibid., s. 12) i og uden for højskolen. Finstens holdninger, der siden har vundet frem i de danske højskolemiljøer, går i retning af en specialisering fremfor almen - eller national - dannelse. Samtidig skal man ikke underkende det forhold, at en gruppering inden for højskolen - tildels identisk med Kredsen omkring Højskolemanifest 2000 - ønsker at fastholde den grundtviske arv. Men i Højskolebladet er det Grundtvig-kritikken, der indtil nu har været mest debatskabende.

I en (E-)mail til Grundtvig skriver forstanderen for Den Skandinaviske Designhøjskole, Birgitte Drud Nielsen, at »Det drejer sig her i år 2002 ikke længere om oplysning og kamp, hvor de onde er de kapitalistiske tyranner, den akademiske eller sociale elite, og de gode er folket« (Birgitte Drud Nielsen, 'Mail til Grundtvig', Højskolebladet, 12, 2002, s. 3), det er blevet uigennemskueligt, hvad der er godt og ondt, og Grundtvig har ikke svaret på de udfordringer, man kan møde i »et ekstremt kompliceret samfund « (ibid., s. 3). Tonen i Birgitte Druds mail er let arrogant, men hendes opfattelse af Grundtvig som utidssvarende er i pagt med tidsånden og dens konkretioner i kritikken af Grundtvig.

At Grundtvig selv i traditionelle grundtvigske institutioner således kommer på anklagebænken, vidner om styrken i disse års opgør med hans status i dansk kultur. Det forholder sig formodentlig således, at de næstfølgende år vil bringe stadig stærkere angreb på hans tanker, idet han samtidig tages op af de højrekræfter, der trods betydelig politisk indflydelse som støtteparti for den nuværende borgerlige regering altid vil blive opfattet som værende på afstand af det danske samfunds »mainstream«. Dermed kunne man formode, at Grundtvigs rolle var udspillet. Tilbage bliver det billede af ham, som den kulturradikalt funderede kritik tegner, et billede, som kritikerne kun kan finde bekræftet i Tidehvervs, Dansk Folkepartis og Den danske Forenings udnyttelse af ham. Inden dette sker, kan det dog være af værdi at vende sig til Grundtvigs forfat- 
terskab for gennem et dyk ned i centrale tekstsammenhænge at undersøge, hvorvidt dette billede er i overensstemmelse med hans tanker og deres udtryk i prosa og poesi. Det er her pointen i nærværende arbejde, at kun en fornyet beskæftigelse med forfatterskabets kristent-teologiske udgangspunkt og nerve formår at ændre billedet af Grundtvig som reaktionær nationalist.

\section{Afslutning: Grundtvig, kristendommen og den danske identitet}

I artiklens indledning strejfedes en komparation af dansk og svensk kultur, idet det her blev hævdet, at kristendommens fremtrædende plads i efterkrigstidens danske kulturhistorie rummer tråde tilbage til Grundtvigs forfatterskab. Samtidig blev en indre modsætning i det gængse Grundtvig-billede blotlagt: det forhold, at Grundtvig og hans tankeverden i vidt omfang fra mellemkrigstiden og frem tolkes som en form for livsfilosofi fremfor som en kristent-teologisk livsanskuelse. Vilhelm Grønbechs centrale betydning for den ikke-kristne, "livsfilosofiske« Grundtvig kom i det følgende til udtryk i forbindelse med redegørelsen for Frederik Borgbjergs socialdemokratiske Grundtvig-reception, men i den videre redegørelse blev det klart, at Grønbech også kunne bruges af teologer som Hal Koch og Kaj Thaning, der brugte inspirationen fra ham $i$ en sine steder genial aktualisering af væsentlige elementer i det kristne menneskesyn. I nærværende arbejde følges imidlertid den kritik af Thanings tese om adskillelsen af kristendom og menneskeliv, som i de senere år er fremført af teologer som Theodor Jørgensen og Helge Grell ${ }^{41}$. Thanings adskillelsestese med dens tendenser til at lade den kristne skabelsesteologi glide over i Grønbechsk livsfilosofi forkastes. I stedet fastholdes Grundtvigs egen beskrivelse af den levende vekselvirkning som tolkningsnøgle i forbindelse med Grundtvigs syn på forholdet mellem kristendom og folkelighed, kirke og kultur. Denne tolkningsmodel danner afsæt for de følgende siders forsøg på at imødegå både Grundtvigkritikken og den højreorienterede Grundtvig-reception, som i de senere år har vundet indpas i Danmark. Det er i den forbindelse den afgørende indsigt, at det element af livsfilosofi, der mere eller mindre udtalt har præget den "profane« Grundtvig-reception siden mellemkrigstiden, både virker spærrende i forhold til Grundtvig-kritikernes forståelse af Grundtvigs egentlige anliggende og $\mathrm{i}$ forhold til den grundtvigske bevægelses evne til at modstå angrebene og give svar, der tager luften ud af en 
opfattelse af Grundtvig som inhuman. Hertil kommer som en væsentlig iagttagelse, at samtlige kritikere (og i virkeligheden også de Grundtvigbegejstrede højrekredse) læser Grundtvig anakronistisk ud fra nutidens kontekst, hvilket forhindrer dem i at fange nuancerne i Grundtvigs begreber såvel som de forhold, han reagerer på i sin sammentænkning af kristendom og moderne træk.

Til en begyndelse gribes fat i Grundtvigs folkelighedsbegreb i et forsøg på både at imødegå de senere års massive kritik af folkelighedens nationalistiske grundtone og Tidehvervsteologiens bestræbelser på at underbetone elementet af universalisme i Grundtvigs forfatterskab. Det er i den forbindelse væsentligt, at Theodor Jørgensens ovennævnte tolkning af forholdet mellem folkelighed og kristendom lader sig udbygge med elementer fra Grundtvigs fortolkningshistorie, der kaster afgørende lys ind over forfatterskabet. Forfatteren Jørgen Bukdahl har i sin ovenfor nævnte, fine, lille bog Norden og Europa, København 1947, og i artikler (J. Bukdahl, 'Det universelt-kristelige mønster i nordisk folkeliv' i Norden og Europa, Hilsen fra Snoghøj, København 1959, s. 54ff.) fra Snoghøj Nordisk-europæiske folkehøjskole peget på det forhold, at folkeligheden for Grundtvig repræsenterer det partikulære, medens kristendommen er bærer af det universelt-menneskelige. Denne afgørende indsigt, som også er implicit tilstede i Theodor Jørgensens ovennævnte arbejde, kaster lys over Grundtvigs modstand mod den »almindelige Menneske-Kiærlighed «. Når Tidehvervs-teologer såvel som Peter Neerup Buhl griber fat $\mathrm{i}$ denne Grundtvigs modstand mod en humanistisk universalisme, overser de over én kam, at Grundtvig ikke dermed mener, mennesket ikke bør have et forhold til menneskeheden som sådan. Grundtvig "skelnede» måske nok mellem kristendom og politik eller folkeliv, men det var ikke for dialektisk at kunne holde dem sammen, som Jesper Langballe advokerer for, men derimod for at lade dem indtræde $\mathrm{i}$ et dynamisk vekselvirkningsforhold, hvor kristendommen også påvirker folkeligheden og fører den egoistiske kærlighed videre i et forløb, der kan beskrives som en vækst. Det er Grundtvigs afgørende pointe, at »Fædernelands-Kiærligheden« skal »stræbe at udvide sig« til »den almindelige Menneske-Kiærlighed « (N. F. S. Grundtvig, 'Menneskehed og Folkefærd betragtede med nordiske Øine', Danskeren, II, 1849, i Vorker i Udvalg v. Hal Koch og Georg Christensen, I-X, VI, s. 355). Grundtvig har selv givet en glasklar formulering heraf i det netop citerede værk: 
Her møder os nu Christendommen, som den høiere Viisdom, der først har lært baade Tyskerne og os, ja, baade Jøder og Groker tillige, at der er et stort Menneske-Liv, som er Roden til alle Folke-Liv, som Grene paa det fælles Stamtræ, og det har vi, som fra Arildstid tilbad under Asken Yggdrasil, nemt ved at fatte, og vi giver gierne Christendommen ret i, at dette Stamtræ maa ikke være goldt som Asken, men skal bære Frugter, som smage ad Roden og komme hele Menneske-Slægten til Gode, saa Folkene maa ingenlunde hade, ødelægge eller opsluge hverandre, men skal, som Grene paa det samme Træ, hjelpes ad til at modstaae Storme, vinde Læ og give Skygge, mens hver bær sine egne Blade, Blomster og Frugter (ibid).

Det er udsagn som dette, som i forening med Grundtvigs egen afvisning af, at hans folkelighedsbegreb er nationalistisk (N. F. S. Grundtvig, 'Om Folkeligheden og Dr. Rudelbach', US IX, s. 89) kan kaste lys ind over, hvilke elementer i forfatterskabet der undslipper både Grundtvigkritikerne og de højreorienterede Grundtvigfortolkere. Nok siger Grundtvig, at man "paa Jorden« aldrig finder »Menneskelighed uden Folkelighed» (N. F. S. Grundtvig, 'Folkelighed og Christendom', US IX, s. 86), - men dermed være ikke sagt, at de forskellige folkelige »menneskeligheder» ikke skal ses i det lys, der udgår fra Kristus. Bestemmelsen af kristendommen som det universelle kaster også indirekte lys ind over Grundtvigs strid med Goldschmidt, forudsat den kombineres med indsigter $i$, at Grundtvigs sprogbrug altid bæres af en række præcise og bestemte betydninger, som man skal være en god kender af hans univers for at kunne gribe i forbindelse med læsningen af ham ${ }^{42}$. Grundtvigs kritikere misforstår ofte væsentlige meningssammenhænge i forfatterskabet, fordi man ikke er opmærksom på ords og begrebers valør og betydning $\mathrm{i}$ Grundtvigs univers, der er karakteriseret af Grundtvigs meget bevidste vilje til at arbejde med og omforme sproget, dvs. hans vilje til at give disse en mere eller mindre ny betydning, der afviger fra andre forfatterskabers ${ }^{43}$. Her lønner det sig sommetider at konsultere den ældre Grundtvig-reception fra det 19. århundrede. Grundtvigs disciple var tættere på ham, end vi er i dag, både med hensyn til den nære kontekst og med hensyn til adgang til mesteren selv, og det er ingen ringere end Askovs første højskoleforstander, Ludvig Schrøder, der kan kaste lys over Grundtvigs brug af begrebet "Giæst«. Dette ord har en præcis betydning i Grundtvigs forfatterskab, der overvejende er positiv i det øjeblik, det kombineres med Grundtvigs frihedsbegreb, og Schrøder 
skildrer, hvorledes det, når det gælder »om menigheden i forhold til menneskelivet og folkelivet « forholder sig sådan, at det af Grundtvig hyppigst brugte billede er billedet af "gjicesten, der kommer at søge hjærterum og husrum hos mennesket « (L. Schrøder, 'Grundtvigs tanker om åndslivets kår i denne verden', i Om skoler for voksne, Kjøbenhavn 1878, s. 58). Det i nærværende sammenhæng afgørende er, at Grundtvig fra 0.1825 kan betegne kristendommen som en i forhold til folkelighed og folkeliv »fremmed Gicest « (N. F. S. Grundtvig, 'Folkelighed og Christendom', US IX, s. 85f. Den danske Statskirke upartisk betragtet, US VIII, s. 82). Som vist af Schrøder er det i den forbindelse Grundtvigs anliggende at pege på, at kristendommen krænkede gæsteretten i de århundreder, hvor den besad et frihedsberøvende herredømme i forhold til det danske folk, men at der i forbindelse med dette misbrug af gæsteretten var tale om først og fremmest den romersk-katolske pavekirkes menneskelige fortegning af kristendommens egentlige væsen. Kristendommen er for Grundtvig aldrig folkelighedens modstander, men dens forbundsfælle, og det er som sådan, kristendommen i sin "fremmedhed" skal virke (N. F. S. Grundtvig, Danskeren, III, s. 744f.). "I Folket er vi som fremmede Giæster «, siger Grundtvig om menigheden, men når gæstevenskabet først etableres i frihed, bringer gæsten med Schrøders ord "rige skatte» og vil stræbe at "tjene» det folk, der lægger hjerte- og husrum til (L. Schrøder, 'Grundtvigs tanker om åndslivets kår i denne verden', i Om skoler for voksne, København 1878, s. 64). Schrøders anliggende i den omtalte tekst er at afdække, hvorledes også »folkeånden «, som skildret af Grundtvig i Nordens Mythologi (ibid., s. 67) er en fremmed i forhold til folket:

Det folkelige åndsliv er som det kristelige i grunden under alle himmelegne en udlænding, en fremmed gjæst. Det har især nu en fattig skikkelse, men gjemmer, som det kristelige, en stor indvortes rigdom. Men det gjælder fremdeles efter Grundtvigs tankegang om åndslivet i det hele, altså om folkeåndens liv så vel som om gudsåndens liv her på jorden, at på samme tid, som det synes fremmed, er der dog noget underligt hjemligt, når det kommer til orde hos det folk, hvortil det har ærinde (ibid., s. 69).

Schrøder slår i den sammenhæng fast, at 
Det første vilkår for åndsvirksomhed er ..., at den må ske i frihed, og kun hvor man frivillig vil give sig ind under folkeåndens myndighed, kan den gjøre sin frugtbare gjerning (ibid., s. 71).

Skal man nu forsøge at bruge Schrøders fortolkning i forbindelse med Grundtvigs krig mod Goldschmidt, er det vigtigt indledningsvis at gøre sig klart, at forholdet her forskubbes noget. Hvor Grundtvig i forbindelse med Helligånden og folkeånden kritiserer menneskers forsøg på at bruge tvang på vegne af disse, er der i tilfældet Goldschmidt tale om en direkte kritik af ham for overhovedet at udtale sig om danske anliggender, en kritik, som med rette støder den moderne læser, der i modsætning til Grundtvig forstår, at Goldschmidt ikke er enten dansk eller jøde, men er begge dele, på den ene side vokset op i Danmark, på den anden side bevidst om sin jødedom, som han dog har et temmelig uafklaret forhold $\mathrm{til}^{44}$. Med rette har Morten Thing talt om det essentialistiske element i Grundtvigs folkelighedsbegreb som en dødvægt i forfatterskabet ${ }^{45}$. Imidlertid er der også tråde til Grundtvigs tale om forholdet mellem kristendom og folkelighed som et gæsteforhold. Goldschmidt prøver ifølge Grundtvig at undertrykke den folkelighed, han som gæst skal tjene. Og det centrale i Grundtvigs syn på Goldschmidt er, at han dybest set har et positivt syn på Goldschmidts »fremmedhed", i og med, at han til en vis grad »modellerer« ham i ikke primært kristendommens, men den mosaisk-kristelige anskuelses skikkelse. Netop dette forhold umuliggør Klaus Rothsteins på s. 214ff. fremførte tolkning. Dette står i forbindelse med Grundtvigs konkretion af, hvad vekselvirkningsforholdet mellem kristendom og folkelighed indebærer. I Nordens Mythologi fra $1832 \mathrm{gør}$ Grundtvig rede for, hvorledes han og hans kirkelige modstandere, naturalisterne af ånd, kan være fælles om ikke troen, men den mosaiskkristelige anskuelse, der som en frugt af troen virker gærende ind på folkelivet og sætter det ind i den universalhistoriske ramme, der giver sig af foreningen af skabelse og genløsning eller genoprettelse af menneskets status før syndefaldet (N. F. S. Grundtvig, Nordens Mythologi 1832, US $\mathrm{V}$, s. 401ff). Elementet af kristelighed i anskuelsen ligger selvfølgelig ikke lige for i Goldschmidts tilfælde, men den »første halvdel« af anskuelsen gør Grundtvig præcist rede for i en enkelt, betydningsfuld sætning, når han foreholder Goldschmidt, at han som jøde er i stand til $i$ en dansk sammenhæng at repræsentere den hebraiske »eiendommelige Beskuelse og Anvendelse af Menneskelivet (Grundtvig, i Danskeren 2. Aarg. 10/11 Nr. 44, s. 693), til hvis højder Grundtvig aldrig selv vil 
kunne nå. Dette kan fortolkes på to måder. Ønsker man som Morten Thing at pege på det »fastlåsende « i Grundtvigs folkelighedsbegreb, kan man fremhæve, at danskeren for Grundtvig aldrig bliver jøde, og jøden aldrig dansker. De færreste mennesker vil i vore dage fremholde så bastant et syn på folkelighedernes eller de nationale identiteters væsen. Vil man derimod fremhæve det element af vorden, af tilblivelse, som Grundtvig har givet så smukt et udtryk i udsagnet om, at »Loven for Folke-Livet ... er ... uophørlig Bevægelse« (N. F. S. Grundtvig, 'Folkevindingen i Danmark ved Omsvinget 1848', i Danskeren IV, 9, 1851, s. 330), fremhæver man, at Grundtvig jo virkelig tilkender den fremmede en rolle at spille i forhold til den hjemlige vært, hvem han med Schrøders ord bringer »rige skatte«. Det dynamiske element, der vitterligt er i Grundtvigs syn på kulturudviklingen og i særdeleshed kristendommens rolle heri, kommer således klart til udtryk.

Sagt i al korthed: billedet af Grundtvig som en frihedens talsmand fastholdes i nærværende arbejde, men det understreges, at man meget tit fejlfortolker både Grundtvigs frihedsbegreb og dets inderste kerne, hvis man ikke forstår, at det frie forhold mellem Gud og menneske her er udgangspunktet, der skal tjene som model også for forholdet mennesker imellem. Frihedsbegrebet leder os naturligt videre til Grundtvigs tanker om social lighed, i og med at de to begreber som hos Borgbjerg har været kombineret i forbindelse med fortolkningen af Grundtvigs indsats i det danske folk.

Også her er det vigtigt at holde sig for øje, at Thaning har uret i sin skarpe adskillelse af kristendom og menneskeliv. Anklagen mod Grundtvig for at være tilhænger af et reaktionært syn på det sociale spørgsmål fremføres med størst dybde af Finn Stendal Pedersen, der i sin afhandling lader et kristent engagement komme til syne i sin kritik af Grundtvig for at fastholde de fattige i rollen som fattige og dermed hindre dem $i$ at nå frem til et stade, hvor de havde overskud til at tage imod evangeliet. Med rette bebrejder Stendal Pedersen Grundtvig, at han lader sig lede af Ricardos, af den engelske socialøkonom Thomas Robert Malthus (17661834) påvirkede syn, at hjælp til fattige vil forøge fødselsoverskuddet og dermed i kraft af et forøget arbejdsudbud presse lønnen ned. Men udover, at han glemmer, Grundtvig i sin kritik af offentlig forsørgelse overvejende sigter mod statens understøttelse af dovenskab, udelader Stendal Pedersen, og i endnu højere grad Henning Tjørnehøj, et væsentligt afsnit i historien om Grundtvigs stillingtagen til det sociale spørgsmål. I den nyeste forskningshistorie er den berømte linje fra Danmarks 
Trøst om den sociale ligelighed blevet underkastet en fortolkning, gennemført af docent, dr. phil Fl. Lundgreen-Nielsen. Lundgreen-Nielsen har påvist, at Grundtvigs begreb om det 》Gylden-Aar« som for ham var at vente i en nær fremtid, har rødder i det jødiske Jubelår, der indtraf hvert 50. år (3. Mosebog, 25). Gennem analyse af første bind af Grundtvigs Haandbog i Verdens-Historien fra 1833 påviser Lundgreen-Nielsen, at dette var et

... resultat af en art social fordelingspolitik: al indenlands gæld blev eftergivet, og arvet jord, der var gået ud af en slægt, faldt tilbage til denne. Den borgerlige hovedsag ved gyldenårsinstitutionen var at sikre selveje og forebygge herremandsvælde, mener Grundtvig, og kombineret med loven om et hvileår hvert syvende år, hvor alle hebraiske trælle frigaves, sikrede det jøderne at bo »i et Land, hvor vel, som allevegne, kun Faa blev meget rige, men hvor endnu Færre blev meget fattige«. Det tykke bind slutter med Kristus, der ifølge Lukas 4.19 (et citat fra Jesajas 61.2) udbasunerer »den ny Tid, som et Gylden-Aar for hele Slægten (Fl. Lundgreen-Nielsen, 'Grundtvig og guldalderens København’ i Grundtvig Studier 1995, s. 118f.)

Knytter man denne sociale - og kristeligt accentuerede - vision om ligelighed sammen med Lars Kaaes analyse af det grundtvigske frihedsbegrebs sociale implikationer i afhandlingen Ikkun som voxne MenneskeBørn. Grundtvig og frihed, i Stykkevis og delt. 5 essays om Grundtvig og grundtvigianisme, udg. v. Tønnes Bekker-Nielsen et. al., Århus 1986, s. 75ff., nuanceres billedet af Grundtvigs syn på det sociale spørgsmål væsentligt. Lars Kaaes analyser, knap omtalt af Stendal Pedersen og ukendte for Tjørnehøj, er så væsentlige, at de burde have spillet en større rolle i forskningen, end tilfældet er. Han peger på, at Grundtvigs kritik af fattighjælp afbalanceres af tanken om »Kiærligheds-Baandet ( ibid., s. 113), samhørigheden mellem rige og fattige som basis for frivillig fattighjælp, og han påviser, at "retten til arbejde« (ibid., s. 114) som en friheds- og altså dybest set en menneskerettighed ligger bag hele Grundtvigs virke, "samfundet skal give den enkelte mulighed for at tjene sit daglige brød « (ibid., s. 115). Grundtvig argumenterede »i realiteten for menneskets ret til at sælge sin arbejdskraft og selv nyde frugterne deraf« (ibid., s. 116) ${ }^{46}$. Grundtvig har træffende talt om »Folkets SelvBesiddelse« som en »utabelig Rettighed «, og således knyttet til ved tanken om menneskerettigheder, - det, han ifølge Langballe skulle have et 
entydigt negativt forhold til (N. F. S. Grundtvig, 'Den danske, den tyske og den franske Sag, Tale i den slesvigske hjælpeforening 14de Marts 1848', Danskeren No $626 / 4$ 1848, s. 218f.). For Grundtvig var menneskets evne til at forsørge sig selv altid et ideal, således som også Vagn Wåhlin viser det i 'Grundtvigs økonomiske tænkning', Grundtvig Studier 1989-90, s. 246ff.. Men når han kunne gå så voldsomt imod statens forsørgelsespligt, skyldtes det ikke, at han ville indskrænke hjælpen til værdigt trængende. Forholdet er det enkle, at Grundtvig var tilhænger af en kirkelig fattigpleje. Dette forhold er blevet "glemt « i den del af Grundtvigs receptionshistorie, der falder efter Kaj Thanings Grundtvigtolkning, samtidig med, at Thaning-tilhængerne, der så med mishag på enhver type af kirkelig »aktivisme« fremfor egentlig forkyndelse, har kunnet støtte sig til, at Grundtvig vitterligt skelnede mellem kristendom og folkelighed og på mange måder fortolkede menneskets fysiskmaterielle jordeliv som et led i dets folkelige livskreds. Forholdet er imidlertid det, at Grundtvig forestillede sig, de trængende skulle hjælpes gennem en kristeligt funderet, frivillig fattighjælp, idet den kristelige næstekærlighed som udfoldet $i$ frihed besad en værdighed, den tvungne statshjælp aldrig ville kunne udvise. De kristne ville få $»$ Lejlighed til at meddele og gøre vel«, men de fattige ville også kunne have »Gavn og Glæde« af, hvad der blev givet som en vennegave (H. Begtrup, VartovPrcester gennem 70 Aar, udg. af Dr. H. P. B. Barfod, København 1926, s. 57). Det var Grundtvigs »frie« menighedskreds, den, der samledes om ham af fri drift og med baggrund i de københavnske vækkelser i hans tid som institutionspræst ved Vartov, der satte menighedsplejen i værk, og i den forbindelse udtalte stifterne i en skrivelse, formodentlig konciperet af initiativtageren, Grundtvigs svigersøn og kapellan P. O. Boisen, at

Oprettelsen af en saadan frivillig Hjælpekasse, der muligen vil blive efterlignet $\mathrm{i}$ andre Menigheder, vil give Haab om at faa det tvungne Fattigvæsen omsider afskaffet (ibid.,s. 58).

På skrivelsen har Grundtvig påtegnet, at han finder, »Denne Kærlighedsgerning er ... aldeles i Kristendommens Aand « og vil blive velsignet af ham, som »selv finder det saligere at give end at modtage», idet menigheden »ikke skal føde Dovenskab eller opelske Lediggang, men ... gladelig komme de virkelig Trængende til Hjælp af den Formue, Han giver, ...« (ibid., s. 58). I Grundtvigs ord kommer det klart til udtryk, at han fremholder Kristus som et forbillede for den kristne, og at han 
betragter den kristnes ejendom som et lån fra Gud, der skal forvaltes $\mathrm{i}$ overensstemmelse med Guds vilje. Grundlæggelsen af Vartovs fattigpleje, i sin struktur udformet med Apostlenes Gerninger 6,1-6 som eksempel, finder sted i 1854 . Der er tale om den første, frivillige, kirkelige fattigpleje i Danmark, og allerede året efter bruges den som eksempel til efterfølgelse af både Grundtvig og hans tilhængere i debatterne i Folketinget. I Boisens forslag ligger, at man giver til menighedens medlemmer og dermed til de personligt vakte kristne i København, men også, at de derved bliver i stand til at »holde sig fri af det tvungne fattigvæsen" (Jakob Appel, Vartov. Trcek af den frie menigheds historie, København 1995, s. 39), der dengang medførte en række ydmygende begrænsninger i menneskers deltagelse i samfundslivet som frie og myndige borgere eksempelvis kunne man miste retten til at stemme og retten til at indgå ægteskab. Netop dette ydmygende aspekt er stærkt fremtrædende i folketingsdebatterne om menighedernes frie fattigkasser, foranlediget af et lovforslag om tilladelse til et frivilligt fattigvæsen, fremsat af grundtvigianeren, provst J. V. Bloch, der bl.a. fremførte, at mennesker altid skulle have fri ret til at indgå ægteskab. I debatten forsvarede Grundtvig over for venstrepolitikeren A. F. Tscherning det lovbundne i forslaget med, at det trods dette drejede sig om at fremme et frivilligt initiativ, og han fremhævede, at tvungen hjælp stødte de fattiges æresfølelse, ligesom han bemærkede, at kommunen kunne ophæve de restriktioner, der fulgte på fattighjælp, såfremt den fik lov af ministeriet. I sin udformning blev loven en blanding af kirkelig indsamling og kommunal uddeling, hvilket medførte, at Grundtvig tog afstand fra den ${ }^{47}$. Episoden afdækker, i hvor høj grad Grundtvig forestillede sig, kristendommen kunne virke højnende på det offentlige liv, og er et eksempel på, at en ensidig opfattelse af Grundtvig som præget af manglende social forståelse kan føre til glemsel af vigtige kilder, der kan nuancere billedet.

Det samme gør sig gældende i forbindelse med diskussionen af den grundtvigske folkeoplysningstradition. På samme måde som Tjørnehøj og Stendal Pedersen i deres kritik dybest set er bestemt af den nutidige kontekst, som velfærdssamfundet afstikker, er kritikerne af den grundtvigske »livsoplysnings" nationale prægning bestemt af dels nynationalismens klaustrofobisk virkende angst for enhver form for fremmed indflydelse, dels kritikken af nationalstaten, som fokuserer på dens utidssvarende præg af en fortid. Af lignende grunde overser Grundtvigs kritikere, at hans dannelsesideal ikke medfører, at folkeligheden lukker sig om sig selv. 
Igen er det her vigtigt at holde sig for øje, at kristendommen for Grundtvig udgør den yderste kontekst for hans virke også i henseende til den fortsatte indsigt i menneskets gudbilledlighed, som for ham udgør oplysningens kerne. Det blev ovenfor klart, at Tidehvervs-teologen Jesper Langballe har store vanskeligheder med Grundtvigs begreb om universalhistorie, som vitterligt også står i modsætning til den ensidige betoning af menneskets overtagelse af sine givne, af kulturel arv, tid og sted determinerede vilkår, som Tidehverv og også Peter Neerup Buhl ser som kristendommens dialektisk-teologiske konsekvens. Grundtvig er - selvfølgelig - ikke dialektisk teolog, al den stund han levede og virkede i det 19. århundrede. Det naturlige modstykke til den dialektiske teologis holden det timelige fast $i$ dets timelighed gennem evangeliets forkyndelse af evighed udgør Grundtvigs begreb om den levende vekselvirkning. Det billede af kristendommen som den fremmede goest, som tegnedes ovenfor, er her igen af afgørende betydning for forståelsen af, hvad Grundtvig sigter imod. Med støtte i Theodor Jørgensen og Jørgen Bukdahl blev det $i$ indledningen til nærværende, afsluttende afsnit gjort klart, at Grundtvig opfatter folkeligheden som det partikulære, der gælder på et sted og for en tid, medens kristendommen som det evige udgør det universelle. Derfor er det også væsentligt at gøre sig klart, hvad det er, Grundtvig mener, når han i Nordens Mythologi taler om den mosaisk-kristelige anskuelse (N. F. S. Grundtvig, Nordens Mythologi 1832, US V, s. 401). For Grundtvig er det afgørende, at de kultursammenhænge, han betragter som væsentlige, bidrager til det samlede billede af mennesket og dermed til menneskets indsigt $\mathrm{i}$, hvorledes det $\mathrm{i}$ folkelighedens fragmenterede form bærer Guds billede, det billede, som først den hele menneskehed gennem kristendommens samlende indflydelse er i stand til at opnå klarhed over. For Grundtvig er kristendommen den stærkeste dynamiske kraft i verdenshistorien, den er det, der i sin vekselvirkning med kulturerne åbner menneskets blik for slægtskabet mellem folkene og det forhold, at menneskeheden, som det fremgik af ovenstående citat, dybest set skal arbejde sammen til fælles bedste. Den vekselvirkning mellem det hjemlige og det fremmede, som ovenfor afdækkedes i forbindelse med en nuancering af det hidtidige billede af Grundtvigs og Goldschmidts strid, står i uløselig forbindelse med forholdet mellem folkelighed og kristendom. Men modtagelsen af kristendommen er som i tilfældet Goldschmidt også her paradigme på det dynamiske forhold mellem den lokale kultur og påvirkninger udefra. Grundtvig har selv givet dette udtryk i sin skildring af den middelalderlige, islandske fristat, af ham 
betragtet som idealet og forløberen for den nordiske dannelse eller vidskab, han aner vil komme:

Nu peger jeg da paa Island og siger til hele Norden: luk dog engang dine Øine op og see, hvad der allerede i Middelalderens, hverken aandfulde eller meget oplyste, men meget lidenskabelige og forvirrede, Dage, kom ud af en Nordisk Forening og fælles Bestræbelse efter en naturlig, Nordisk Dannelse og Vidskab! See, om Isloenderne, disse det nordiske Himmelbjergs historiske Vogtere, smaalig indskrænkede sig til hvad de havde bragt med sig, eller om de ikke holdt sig i levende Vexelvirkning med hele den dem bekjendte Verden; lærde ikke blot Bogstavskrift af Angelsachserne, og beskrev med samme Flid Begivenhederne i hele Norden, og hvor de vidste Beskeed, som dem paa Island, men lærde ogsaa Latin, Tydsk og Fransk, og tilegnede sig, paa Modersmaalet, hvad de deraf fandt nyttigt eller fornøieligt, ja see, om ikke selv Christendommen, der dog haanede deres gamle Guder og forkyndtes ingenlunde apostolisk, fandt saa let Indgang hos dem, som hos noget Folk under Solen (N. F. S. Grundtvig, De historiske Minders Betydning, København 1845, s. 8).

Grundtvigs smukke billede af et folk, der kender sig selv, og netop derfor er i stand til i en stadig vekselvirkning at tage imod påvirkninger udefra - at tage imod den gaest, der fører til den gamle religions fald - er så klart, at det næsten er helligbrøde at kommentere det. Derfor vil jeg indskrænke mig til at pege på, at Grundtvigs dannelsesideal i sin stærke og bærende form grundlæggende må betragtes som en udfoldelse af den vekselvirkning mellem Gud og menneske i det levende ord, der udgør hjertet $i$ hans anskuelse. For Grundtvig er det ikke nok at arbejde livsfilosofisk med menneskelivet. Menneskelivet bliver for ham først »klart « i kraft af den kristne fortolkning, han giver det på baggrund af sine modernitetserfaringer og de idéer om frihed og lighed, som i den sammenhæng kommer til ham. Til Grundtvigs tidsfølge, og dermed hans angivelse af forståelsens forudsætninger, som kommer til udtryk i hans berømte linje om »Menneske først og Christen saa«, lægger sig da de afsluttende linjer i det berømte digt "Stræbe da hver paa denne Jord/Sandt Menneske at være/Aabne sit Øre for Sandheds Ord,/Og unde Gud sin Ære;/ Er Christendom da Sandheds Sag/Om Christen ei han er i Dag/Han bliver det i Morgen!« (N. F. S. Grundtvig, 'Menneske først og Christen saa', i Grundtvigs Sang-Voerk I-V, III, s. 156 og 206ff.). Og nået 
så vidt spørger man sig selv, om ikke den eskatologiske endetidsbegivenhed, hvor »alle Modersmaal « skal smelte sammen for Grundtvig, ikke blot allerede foregribes på proleptisk vis i den gudstjenstlige takkesangs »Offer-Skaal« (N. F. S. Grundtvig, 'Opblomstrer nu, Guds Kirkevange', GSV I-V, København 1983, III No. 266, s. 514ff.), men også ligger bag den nye »Folke-Blanding «, og dermed det kulturernes samvirke, som Grundtvig ligesom middelalderens folkeblandinger (Grundtvig, Nordens Mythologi, 1832, US V, s. 460f.) ser som nødvendig for verdensløbets rette vækst hen imod Guds rige.

Noter

1. Martin A. Hansen citerer i Leviathan, København 1956, $81 \mathrm{ff}$, indirekte Grønbechs ord om, at Grundtvig peger fremad mod en ny kultur. Martin A. Hansens positive forhold til Grundtvig kommer også til udtryk i han promovering af Det danske Selskab, der under ledelse af grundlæggeren Folmer Wisti på mange måder er udtryk for det officielle Danmarks bestræbelser på at give højskoletanken videre til udlandet $i$ efterkrigstiden (Martin A Hansen, 'Frit Ord', i Berlingske Tidende 4/12 1949). Se også Thomas Rørdam, 'Det danske Selskab i Søgelyset', Dansk Udsyn 1971, s. 36ff. og Folmer Wisti, 'Grundtvig ud over grænserne', Dansk Udsyn 1983, s. $33 \mathrm{ff}$.

2. En anden kilde til den udbredte forståelse af Grundtvig som livsdyrker kunne være Troels Lund, Bakkehus og Solbjerg, I-III, København 1920-22, I, s. 170ff., hvor Troels Lund udkaster den vidtløftige og fantasifulde tese, at Grundtvigs »Den signede Dag« har hedenske rødder.

3. Til Grønbech, se Armin W. Gertz, 'Vilh Grønbech.' i Den store danske Encyklopcedi, VIII, s. 17 og A. Hvidtfeldt, 'Vilhelm Grønbech', Dansk Biografisk Leksikon, V, s. 348ff.

4. Dansk litteraturhistories "grand old man« professor, dr. phil. F. J. Billeskov Jansen har udtrykt det således: ॥Vi danske er vel ikke en nation, der fundamentalt styres af religiøse motiver. Alligevel danner to mærkelige landsmænd, to religiøse genier, fundamentale elementer i vor åndsform" (F. J. Billeskov Jansen, 'Grundtvig og Kierkegaard', i Grundtvig og Kierkegaard, med ni andre åndshistoriske essays, København 1996, 47. I dette værk registrerer man glidningen fra kristendom til almen humanistisk livstolkning, når forfatteren om Grundtvig skriver »Gudskelov, for det frie ord mellem mennesker er selve livet i Grundtvigs verden, nøglen til hans univers af begreber, ...« (ibid., s. 71). 
5. Til Erik Aalbæk Jensens karakteristik af dansk identitet, se Kim Arne Pedersen, 'Hvad betyder det grundtvigske i dag?' i $O$ dejlige Land, Vartovbogen 1998, s. 54ff. Begrebet kulturradikalisme bruges i nærværende arbejde lidt upræcist om både litteraturhistorikeren og kritikeren Georg Brandes' (1842-1972) moderne gennembrud fra 1872 og dets karakter af frigørelsestænkning og om mellemkrigstidens egentlige kulturradikalisme som udtryk for en videreførelse af »Brandes' kritiske videnskabelighed" gennem hyldesten til en »åndelig åbenhed«, der i "respekten for mennesket « og menneskers samliv »i lighed og frihed « finder elementer til et kulturprogram og en social frigørelsesbevægelse (Hans Hertel, 'Kulturradikalisme', i Den store danske Encyklopæedi, XI, s. 377).

6. Det er således væsentligt, at teologen og Jakob Knudsen-forskeren, redaktøren af den kirkelige grundtvigianismes blad DanskKirketidende, Henrik Wigh-Poulsen, i dette blads nummer 17, 154. årg., 30. august 2002, tager afstand fra Dansk Folkeparti i sin leder. Når det gælder folkehøjskolen, er det betegnende, at den på det seneste har udarbejdet programmer til integration af indvandrere i forbindelse med højskoleophold, (Erik Lindsø, 'Højskole og integration', i Højskolebladet 12, 2002, s. 16). Samtidig svækkes Grundtvigs indflydelse i folkehøjskolen i disse år, se nærværende artikel s. $220 \mathrm{ff}$.

7. Leif Bork Hansen har givet udtryk for dette på konferencen Grundtvig og Kierkegaard - en samtale på høje tid, arrangeret af det danske Søren Kierkegaard-center og Grundtvig-Akademiet i maj 2002. Bork Hansens synspunkter ligger formodentlig bag Lilian Munk Rosings bidrag i dagbladet Information d. 22/3 2002, omtalt i nærværende arbejde s. 211.

8. Til receptionshistorie, se Johann S. Koch, Walter Schmitz, 'Rezeption', i Literaturlexikon, Begriffe, Realien, Methoden 1-15, 14, München 1993, s. 288ff. Reinhart Kosellecks modernitetsbegreb er bl. a. fremstillet i R., Koselleck, Vergangene Zukunft, Frankfurt a. M. 1984. Til begrebshistorien og dens socialhistoriske forankring, se Uffe Østergård, og Jan Ifversen, Begreb og historie, Århus1996, s. 14ff. Uffe Østergård giver her en fremstilling af skolens tematisering af forbindelsen mellem "samfundshistorie" og »begreber og deres ændring", idet han skildrer, hvorledes begrebshistorien "sætter en generel betydningsteori ind i en historisk kontekst" (ibid., s. 23ff.).

9. I forbindelse med Gundtvigs forhold til nationalismen som ideologi er artiklen her inspireret af den norske nationalismeforsker Dag Thorkildsens bestræbelser på at tolke grundtvigianismen ud fra Anthony Smiths og John Hutchinsons opfattelse af nationalismen som svar på den identitetskrise, som giver sig af mødet mellem den moderne, rationelle stat og en førmoderne verdensanskuelse. Thorkildsen arbejder med den gruppe af 
nationalister, som Hutchinson betegner som »moral innovators" (Dag Thorkildsen, 'Grundtvigianisme og nasjonalisme i Norge i det 19. århundre', KULTs skriftserie nr. 70, Oslo 1996, s. 17f. og 19).

10. Til folkelighedsbegrebet se Kim Arne Pedersen, 'Hvad er folkelighed? glimt af folkelighedsbegrebets historie', i Folkelighed år 2000 2, Vartovkonferenceserie nr. 2, København 2002, s. 26ff.

11. Pio fæstner sig ligesom Edv. Brandes (se nærv. arb. s. 188f.) ved Grundtvigs frihedstanker som hans væsentligste indsats og skriver om Grundtvig, der på det tidspunkt gik i sit niogfirsindstyvende år: »At den meget gamle Mand ikke har kunnet følge med den rask fremadskridende Tid, er naturligt; men han har unægtelig vist Mod og Kraft i Frihedskampen efter sin Samtids Begreber, og det er i Reglen Alt, hvad man kan fordre af en Mand" (L. Pio, i Socialisten 5/5 1872).

12. Til nygrundtvigianismen, se A. Pontoppidan Thyssen, Den nygrundtvigske Bevoegelse med scerligt Henblik paa den Borupske Kreds, I, 1870-1887, København1957, Roar Skovmand, Folkehøjskolen i Danmark 1841-1892, København 1944, s. 312ff. Til et generelt billede af den ældste grundtvigianisme, se Hans Jensen, 'Brud og Sammenhæng i dansk Aandsliv efter 1864',i Kirkehistoriske Samlinger, 6, VI, 1943, s. 270ff.

13. Se hertil A. Pontoppidan Thyssen., Den nygrundtvigske Bevæegelse, $329 \mathrm{ff}$. og til en udførlig skildring af Edv. Brandes og grundtvigianismens kontroverser, H. Stangerup, Kulturkampen, I-II, København 1946, II, s. $239 \mathrm{ff}$.

14. Til redegørelsen for accepten af Grundtvig i ikke-grundtvigske miljøer og sammenhænge i mellemkrigstiden, se Kim Arne Pedersen, Grundtvigianisme og Grundtvig-forskning Danmark og udlandet 1914-2002, upubliceret manuskript, Center for Grundtvig-studier, 2002, s. 1-100.

15. Derimod stod Grundtvig svagt i den etablerede, akademiske universitetsteologi. Dogmatikeren, professor I. P. Bang (1865-1936) havde været en enlig svale. J. Oscar Andersen holdt alene øvelser over ham (H. Høirup, Så fjern og dog så noer. Erindringer, Herning 1991, s. 98) og kirkehistorikeren, professor Valdemar Ammundsen (1875-1936) udformede først sin kritiske, men »medtænkende« stillingtagen til Grundtvigs tanker om nationalitet efter sin udnævnelse til biskop over det efter genforeningen oprettede Haderslev Stift i 1922 (J. H. Schjørrring, 'Der nationale Grundtvig und seine Wirkungsgeschichte' i Grundtvig Studier 1999, s. 183ff.) Samtidig fortælles det af teologiske Grundtvigforskere, at deres akademiskteologiske interesse for Grundtvig, som for mange var en del af den personlige baggrund, netop udvikledes i disse år under inspiration fra den dialektiske teologi (H. Høirup, Så fjern og dog så noer. Erindringer, Herning 1991, s. 100). 
16. R. Skovmand, 'Johan Borup', i Dansk Biografisk Leksikon, II, 390f. Som eksempel på Borups brobyggende virke i forhold til socialismen kan nævnes hans forhold til P. Manniches internationale højskole, Lawson, Max, International People's College. A Celebration of 75 Years of Working for Peace and international Friendship, København 1996, s. 16.

17. At Vilhelm Grønbechs Grundtvigtolkning skal ses i dette lys, fremgår af litteraturhistorikeren Emil Frederiksens jubilæumskronik i Berlingske Tidende 3/9 1972, i hvilken han tegner et personligt billede af sit forhold til Grundtvig i årene fra mellemkrigstiden og op til 1972.

18. Til Lehmanns Grundtvigtolkning se Ole Vind, 'Lehmanns bog om Grundtvig' i Edvard Lehmann og religionshistorien, København 2002, 79ff., til Borup, R. Skovmand, 'Johan Borup', i Dansk Biografisk Leksikon, I-XIV, II, København 1979, s. 390f.).

19. Borgbjergs begejstring for det nordiske underbygger Niels Finn Christiansens kritik af Uffe Østergård, når denne hævder, at ideen om den såkaldt »nordiske model« bliver til i et ikke-nordisk forfatterskab. (Niels Finn Christiansen, 'Forskellenes Europa', i Mangfoldighedens pris, 176). Bag Borgbjergs tale skimter man foruden naturligvis Grundtvigs begejstring for Norden også Hartvig Frisch's Pest over Europa, som netop udkommer i 1933, det år, Grundtvigs 150 års fødselsdag fejres.

20. Se hertil Kersti Blidberg, 'Ideologi och pragmatism, samarbetet inom socialdemokratisk arbeterrörelse 1930-1955', Den jyske historiker, 69-70, s. $132 \mathrm{ff}$.

21. Ove Korsgaard, 'To diskurser i den grundtvigske tradition', i Folkelighed år 2000, Vartovs konferenceserie nr.1, København 2000, s. 37). Ove Korsgaard gennemfører sin tolkning på grundlag af inspiration fra Jacob Andersen, Fra folkestyre til foellesstyre, strategier for en demokratisk magtovertagelse, København1998 og Uffe Østergård, Europa. Identitetog identitetspolitik, København 1998, s. 305ff. Se også Ove Korsgaard, 'Folkeoplysning, demokrati og den europæiske union', i Uddannelse, 8, 1999, s. 50ff. og Ove Korsgaard, Demosstrategien, Arbejdspapir Nr. 5, 1999, under Forskningsprojektet Voksenuddannelse, Folkeoplysning og demokrati, København 1999.

22. Med denne tolkning af Hal Koch lægges der afstand til den fremstilling af Koch som bestemt af en overvejende national interesse, som Ole Vind gennemfører i værket Grundtvigs Historiefilosofi, København 1998, s. 20ff. og i artiklen 'Lehmanns bog om Grundtvig' i Edvard Lehmann og religionshistorien, København 2002, s. $79 \mathrm{ff}$.

23. Det er træffende blevet sagt, at den Thaninginspirerede debatbog om folkehøjskolen, Højskolen til Debat 1961 »givetvis« »havde « »større indflydelse ...end debatten 11 år tidligere« (P. Nyboe Andersen, Hal Koch og Krogerup, Odense 1993, s. 228) - den debat, hvori Hal Koch var hoved- 
personen.

24. Se hertil Kim Arne Pedersen, Hvad er folkelighed? glimt af folkelighedsbegrebets historie' i Folkelighed år 2000, Vartovs konferenceserie nr. 2, København 2002, s. 37f.

25. Se hertil Ove Korsgaard, Kampen om lyset. Dansk voksenoplysning gennem 500 år, København 1997, s. 390.

26. Kim A. Pedersen, 'Hvad er folkelighed? Glimt af folkelighedsbegrebets historie', i Folkelighed år 2000, Vartovs konferenceserie $n r$. 2, København 2002, s. $37 f$.

27. Et præcist billede af denne situation finder man hos den svenske politolog Carl-Einar Stålvant: »1989 fick djubgående verkningar. Cementerade sammanhang, övertygelser och konstellationer upplöstes. Använda orienteringspunkter miste sin betydelse då hele det europeiska landskapet förändrades. Ingen part lämnades oberörd. Historiska djubstrukturer vällde fram som samtidsformande faktorer. Två rötter till trendbrotten är uppenbara. De är Sovjets ändrade politik och EG's vitalisering« (CarlEinar Stålvant, 'Vägar till inflytande i Norden', Norden i det nye Europa. En rapport fra de fire nordiske utenrikspolitiske instituttene og universitetet i Reykjavik, Oslo 1991, s. 151). Netop vitaliseringen af det europæiske fællesmarked havde baggrund i »Den europeiska identitetsdebatten - som kan sägas ha nytänts av Milan Kunderas artikel om »Mitteleuropa från 1985 - « (Stålvant, s. 154), dvs. det forhold, at »1980'ernes nye interesse for Europas kulturelle identitet, som især afspejlede sig i den europæiske akademiske debat, gjorde det $\mathrm{i}$ det hele taget lettere at vinde tilslutning til nye ambitiøse integrationsplaner $\mathrm{i}$ de oppositionelle eliter. Ved at fremstille projekt 1992 som et »identitetsskabende« projekt, et led i en art systemkonkurrence med USA og Japan, lykkedes det $\mathrm{i}$ vid udstrækning kommisionspræsident Delors at opfange disse strømninger « (Thomas Petersen, 'På vej mod EF-unionen i Norden', Norden i det nye Europa, s. 81).

28. Til Søren Krarups Grundtvig-reception, se Søren Krarup, 'Da bløder mit hjerte i mig', Tidehverv no 6, 67. årg. 1993. Til Krarup og Dansk Folkeparti, se Søren Krarup, 'I undergangens angst', tale v. Dansk Folkepartis landsmøde, Tidehverv nr. 10. 71. årgang, 1997. Sit brud med den store, borgerlige avis Jyllandsposten, hvor han i mange år var fast skribent, har Krarup skildret i 'Jyllands-Postens forvandling', Tidehverv, nr. 8, 66. årg. 1992, s. $170 \mathrm{f}$.

29. Hans Hauges indlæg 'Hvor går grænsen?' i Dansk Kirketidende, 11, 1997, blev årsag til en langvarig strid om Hauges redaktionelle linje.

30. Mere informative end de nævnte kronikker er en række artikler og interviews, der har behandlet temaerne grundtvigianisme, EU og indvandring (Kristeligt Dagblad 22/5 1998, Jyllands-Posten 23/5 1998, Kristeligt 
Dagblad 28/1 2001).

31. Bunkenborg bruger her mytebegrebet entydigt negativt. En mere positiv anvendelse af begrebet myte finder man hos Ove Korsgaard, der i Kampen om lyset, København 1996, s. 171, betitler et afsnit Myten Grundtvig.

32. Morten Thing har udover det ovennævnte arbejde skrevet sammenhængen ind i bogen Den historiske jøde, København 2001, se Georg Metz i Politiken 7/12 2002.

33. Morten Things analyse af sammenstødet mellem Grundtvig og Goldschmidt går mere i dybden end Rothsteins, men indeholder også nogle temmelig vidtgående konklusioner, hvad angår forekomsten af mulige karikaturer af Goldschmidt andre steder i Danskeren. Striden er behandlet $i$ andre sammenhænge, udførligt og kritisk over for Grundtvig af Morten Bredsdorff (Morten Bredsdorff, 'Striden mellem Grundtvig og Goldschmidt' i Grundtvig Studier 1974, s. 26ff). Klaus Rothsteins upræcise citatgengivelse gav anledning til en længere polemik i Weekendavisen, behandlet af denne strids anden part Knud Michelsen i Citatkrigen. 'Et lærestykke for gamle og nye danskere', i Under det kreative hvoelv, Festbog til Tove Borre og Ørslev Kloster, Viborg 2001, s. 129ff. En nuanceret og skarp fremstilling, der sætter Grundtvigs og Goldschmidts uenighed i perspektiv af diskussionerne om nationalstat i det 19. århundrede, fremhæver, at Grundtvig ikke frakender Goldschmidt statsborgerskab og endelig peger på den manglende antisemitisme $\mathrm{i}$ Grundtvigs angreb, er givet af Ove Korsgaard, (Ove Korsgaard, 'Fejden mellem Grundtvig og Goldschmidt', i Images of the World, globalisering og kulturel mangfoldighed, København 2001, s. 84ff.).

34. Vil man forstå Ole Vind, er det vigtigt at holde sig for øje, at han mener, de nationalistiske elementer i Grundtvig, som han fremanalyserer, er blevet underkastet en fortegnende glemsel $i$ især den nyere receptionshistorie efter Anden Verdenskrig, Ole Vind, 'I Grundtvigs Fædreland', Kronik i Politiken 8/9 2001. Radioudsendelsen Agenda 20/1 2001, P1.

35. Som omtalt udgør Ole Vinds forskning baggrunden for de næunte, yderst knappe analyser, der på intet tidspunkt har kontekst eller referencer med, uden at Ole Vind derfor kan gøres ansvarlig for alt, hvad Axel Karlsson skriver. Imidlertid genfinder man Ole Vinds fremhævelse af Grundtvigs begejstring for etnisk renhed $i$ hans store, skarpt analyserende disputats om Grundt vigs historiefilosofi, som fremkom i 1998. Ole Vinds tese er i øvrigt ikke ny. Henvisningen til Fichtes betydning for Grundtvigs nationalitetsbegreb findes i H. Høffding, Danske Filosofer, København 1909, s. 58f. - et værk, Ole Vind ikke omtaler.

36. Se eksempelvis Peter Neerup Buhl, 'Trudslen mod nationen',i Tidehverv, nr.6, 66, Årg. 1992, s. 100f.

37. Tjørnehøj skriver bevidst om Grundtvigs stilling i dansk åndsliv: »Når det 
i den grad er blevet ignoreret, Grundtvig politisk og socialt var så temmelig reaktionar, er forklaringen vel bl.a. den, at Danmarkshistorien $i$ vor tid ofte er blevet skrevet af grundtvigianere. Hertil kommer at Grundtvig skrev, så kjorligt og tilsyneladende hjerteligt om folket of folkeligheden og folkeånden og danskerne, at man helt glemte, at folket - hele folket - for Grundtvig voesentligst var et åndeligt anliggende. Han omgikkes kun nфdigt og derfor sjceldent menigmand « (ibid., s. 25).En mere dybtgående kritk af Grundtvigs sociale tænkning end Tjørnehøjs findes i M. Ågerup, 'Langt højere dværge', Kronik, Information 4/9 2002.

38. Steen Busck hører selv hjemme i denne tradition og retter i det nævnte arbejde et voldsomt angreb mod landbohistorikeren Claus Bjørn, der i sin historieskrivning ifølge Busck med en række nødvendige revisioner følger en kun delvist afmytologiseret udgave den danske bondestands selvforståelse, af Busck karakteriseret som en mytisk tiltro til, at middelalder og nyere tid repræsenterer et fald fra oldtidens frie bondestand, et fald, der først rettes op på i slutningen af 1700-tallet og frem (Steen Busck, 'Friedlev Skrubbeltrang og landbohistorien', i Mangfoldighedens Pris).

39. Stendal Pedersen har publiceret en engelsksproget artikel i Canada og har således taget skridt til, hvad han opfatter som en kritisk nuancering af Grundtvig-myten i dansk påvirket, udenlandsk Danmarkshistorie (Finn Stendal Pedersen, 'The Politician Grundtvig (1783-1872). A liberal in the Danish Constituent Assembly of 1849', Scandinavian Canadian Studies XV, 1998, s. 55ff.).

40. For Ehlers må der være tale om et selvopgør. Hans første videnskabelige arbejde, En lokal grundtvigsk bevagelse. Etableringen af grundtvigske institutioner i Nordvest-Sjalland, København 1983, s. 69ff., er blevet til på baggrund af 1970'ernes ovenfor omtalte interesse for »det grundtvigske « $i$ dansk kultur, og han har i 'Den grundtvigske selvbesindelse - igen', i Højskolen til debat 1984, red. Finn Slumstrup, København 1984, s. 61ff. givet et ganske vist ikke ukritisk og unuanceret forsvar for den af Aage Møller grundlagte »mytologiske højskole«, der sigtede mod at genindsætte de nordiske myter i deres ret som kilden til livsoplysning.

41. Theodor Jørgensen, 'Adskillelse og vekselvirkning - om Grundtvigs syn på folkelighed og kristendom, 1986', i Korset i Altet, København 1995, s. 165ff.; Helge Grell, Skaberånd og folkeånd, En unders $\emptyset$ gelse af Grundtvigs tanker om folk og folkelighed og deres forhold til hans kristendomssyn, København 1988; Menneske først - Helge Grells Grundtvig-disputats til debat, red. J. H. Schjørring, København 1988.

42. Professor, dr. theol. Regin Prenter har træffende sagt, at den »udbredte forestilling om ordrigdommen og snakkesaligheden i Grundtvigs prosa er helt vildledende «. Prenter hævder herover for, at »Grundtvigs ordvalg er præcist, og den logiske sammenhæng i hans ofte langstrakte perioder meget 
stram« (R. Prenter, 'Grundtvigs treenighedslære', i N. F. S. Grundtvig, Theolog og Kirkelcerer, Christiansfeld 1983, s. 55).

43. Professor, dr. theol. K. E. Bugge er en skarp iagttager af dette forhold og har $\mathrm{i}$ forbindelse med både det grundtvigske folkelighedsbegreb og Grundtvigs politiske tænkning peget på Grundtvigs omhu med at forme egne udtryk til erstatning af fremmedord, udtryk, der tilføres en delvist afvigende betydning, K.E. Bugge, 'Grundtvigs syn på folkelig dannelse dets muligheder før og nu' i Spor i sne, København 1999, s. 23ff. og K.E. Bugge, 'Folkelighed, folkekultur og nationalstat', i Folkelighed år 2000, Vartovs konferenceserie I, København 2001, s. 7ff.

44. Se hertil Morten Bredsdorff, 'Striden mellem Grundtvig og Goldschmidt' i Grundtvig Studier 1974, s. 26ff.).

45. Grundtvigs forhold til jødedommen er behandlet i Thyge V. Kragh, Grundtvigs syn på Israel, København $1971 \mathrm{og}$ Axel Torm, 'Grundtvig og Israel' i Dansk Teologisk Tidsskrift, 1985, også trykt som Han sang Israels Guds salmer, Christiansfeld 1985.

46. »Den private ejendomsret og retten til at sælge sit arbejde på lige fod med andre viser, at Grundtvig argumenterede for en anden lighed: lige muligheder for alle« (Lars Kaae, s. 118). Kaae fremhæver også, hvorledes Grundtvigs tænkning styres af spørgsmålet om fordelingen af ejendomsretten til jorden (ibid., 120).

47. Se hertil Rigsdagstidende $1855 \mathrm{nr} .8$, sp. 107, 131ff., nr. 97, sp. 130ff., 1856, nr. 98, sp. 157ff., nr. 176, sp. 279ff., nr. 189, sp. 2996ff. Jeg takker kirkehistorikeren, provst Arne Pedersen for henvisningen. 